MARCUS VINICIUS ARMANI ALVES

\title{
A Fazenda Pública no sistema multiportas: perspectivas a partir do contencioso do Estado de São Paulo
}

Tese de doutorado

Orientador: Professor Doutor Marcelo José Magalhães Bonizzi

UNIVERSIDADE DE SÃO PAULO

FACULDADE DE DIREITO

São Paulo-SP

2020 



\section{A Fazenda Pública no sistema multiportas: perspectivas a partir do contencioso do Estado de São Paulo}

Tese de doutorado apresentada à Banca Examinadora do Programa de Pós-Graduação em Direito, da Faculdade de Direito da Universidade de São Paulo, como exigência para obtenção do título de Doutor em Direito, na área de Direito Processual Civil, sob a orientação do Professor Doutor Marcelo José Magalhães Bonizzi.

UNIVERSIDADE DE SÃO PAULO

FACULDADE DE DIREITO

São Paulo-SP

2020 
Catalogação da Publicação

Serviço de Biblioteca e Documentação

Faculdade de Direito da Universidade de São Paulo

Alves, Marcus Vinicius Armani

A Fazenda Pública no sistema multiportas:

perspectivas a partir do contencioso do Estado de

São Paulo; Marcus Vinicius Armani Alves ;

orientador Marcelo José Magalhães Bonizzi -- São Paulo, 2020

$303 \mathrm{p}$.

Tese (Doutorado - Programa de Pós-Graduação em Direito Processual) - Faculdade de Direito, Universidade de São Paulo, 2020

1. Fazenda Pública. 2. Sistema multiportas. 3. Poder Público. 4. Estado de São Paulo. 5. Brasil. I. Bonizzi, Marcelo José Magalhães, orient. II. Título. 
BANCA EXAMINADORA 

Aos meus amados pais Américo e Hildely, aо meи irmão Carlos, à minha cunhada Ítala e à tão esperada Catarina. Aos meus avós Mario Armani e Amélia Andreoni Armani, em memória.

À minha sogra Rose, meu cunhado Beto e minha cunhada Ana Luíza. Ao tio João e à avó Angelita. Ao meu sogro Carabed, em memória.

Por fim, à minha amada esposa Carminha, pela paciência, e à nossa amada Beatriz, que nasceu junto com este doutorado. 



\section{AGRADECIMENTOS}

O presente trabalho é fruto, antes de tudo, do incentivo do amigo e orientador Marcelo Bonizzi, que em ato contínuo ao mestrado, incentivou-me a concorrer a uma vaga no doutorado, aceitando-me novamente em nossa querida Faculdade de Direito do Largo de São Francisco.

Pude comprovar pessoalmente porque tantos alunos, ao concluírem o mestrado, não continuam a pesquisa acadêmica. Por diversos momentos, achei que não conseguiria concluir o presente trabalho. Diversos foram os desafios pessoais e a superação da vida profissional. Realmente, é difícil ser pesquisador no nosso País.

Estimulado pela linha de pesquisa que o Professor Marcelo Bonizzi vem desenvolvendo na Universidade de São Paulo, abordamos o tema sistema multiportas envolvendo a Fazenda Pública, associando de certa forma nossa vivência de quase quinze anos no contencioso da Procuradoria Geral do Estado e de vinte anos de contencioso desde o início em 1999, como estagiário do Departamento Jurídico XI de Agosto, estagiário na PGE e no escritório da Professora Priscila Correa da Fonseca, onde optei pela carreira pública. Aprovado aos 25 anos, chego aos quase 40 anos de idade e vejo que o contencioso precisa mudar.

De certa forma, corri o risco no presente trabalho de repetir meu tema de mestrado: a Fazenda Pública na arbitragem, defendido em 2016 e publicado em 2019. Para tanto, procurei dar uma abordagem mais prática e evitar o texto anterior, mostrando como o Estado de São Paulo tem à sua frente um grande desafio para diminuir a litigiosidade que aflige não somente a população, como os próprios procuradores do estado.

O maior desafio, de fato, é a mudança da postura do contencioso, não somente do Estado de São Paulo, mas dos grandes litigantes em massa. A prova disso é que os meios legais estão aí a disposição, contudo não são usados.

Agradeço novamente aos meus professores da graduação, mestrado e doutorado, em especial a Carlos Alberto Carmona, Antônio Carlos Marcato, Flavio Yarshell, Heitor Sica, Gustavo Justino de Oliveira, Carlos Alberto de Salles, Floriano Azevedo Marques, Victor Schein e Edmir Araujo Netto. 



\section{RESUMO}

ALVES, Marcus Vinicius Armani. A Fazenda Pública no sistema de justiça multiportas: perspectivas a partir do contencioso do Estado de São Paulo 2020. 303 p. Tese (Doutorado em Direito) - Faculdade de Direito da Universidade de São Paulo, São Paulo, 2020.

A presente tese analisa brevemente a figura da Fazenda Pública no sistema de justiça multiportas, tendo como corte metodológico a análise do sistema legislativo existente, bem como o estudo do contencioso do Estado de São Paulo. Para isso, em uma parte introdutória, discorre-se brevemente sobre contencioso de massa do Estado de São Paulo. Na primeira parte, estuda-se o sistema de múltiplas portas, sua aplicação à Administração Pública, sobretudo a conciliação, a mediação e a arbitragem. Na segunda parte, detém-se no nos acordos administrativos para a solução de conflitos. Por fim, na terceira parte, o presente estudo enfoca a negociação e o desenho de solução de disputas envolvendo a Fazenda Pública.

Palavras-chave: Fazenda Pública; Sistema multiportas; Poder Público; Estado de São Paulo; Brasil. 


\begin{abstract}
ALVES, Marcus Vinicius Armani. The public administration in the multidoor courthouse system: perspectives deriving from the litigation scenario in the State of São Paulo. 2020. 303 p. Thesis (Doctor in Law) - Faculdade de Direito da Universidade de São Paulo, São Paulo, 2020.

The present thesis briefly addresses the figure of the Public Administration in the Multidoor Courthouse System, having as a methodological cut the analysis of the existing legislative system, as well the study of the litigation scenario in the State of São Paulo. For this aim, the introductory part is intended to briefly discuss the massive litigation in the State of São Paulo. The first part aims at discussing the Multidoor Courthouse System and its application in respect to the Public Administration, particularly in respect to conciliation, mediation and arbitration. The second part is destined to study conflict resolution's administrative agreements. Lastly, the third part of the present thesis addresses the negotiation and the design of resolution of conflicts involving the Public Administration.
\end{abstract}

Key-words: Public Administration; Multidoor Courthouse System; Public Power; State of São Paulo; Brazil. 


\section{RIASSUNTO}

ALVES, Marcus Vinicius Armani. La Pubblica Amministrazione nel sistema multi-porte: prospettive del contenzioso nello Stato di San Paolo. 303 p. Tesi (Dottorato in Giurisprudenza) - Faculdade de Direito da Universidade de São Paulo, São Paulo, 2020.

La presente tese analizza, in modo sintetico, la posizione della pubblica amministrazione all'interno del sistema della giustizia multi-porte, adottando come metodologia quella dell'analisi del sistema normativo esistente, insieme allo studio del contenzioso dello Stato di San Paolo. A questi fini, nella parte introduttiva, trattiamo, per sommi capi, del contenzioso di massa nello Stato di San Paolo. Nella prima parte, è stata effettuata l'analisi del sistema multi-porte, la sua applicazione nell'ambito della pubblica amministrazione, con particolare riguardo alla conciliazione, mediazione e arbitrato. Nella seconda parte, sono stati studiati gli accordi amministrativi per la risoluzione dei conflitti. Infine, nella terza parte della tesi è stata analizzata la negoziazione e la configurazione della risoluzione delle controversie che coinvolgono la pubblica amministrazione.

Parole-chiave: Pubblica Amministrazione. Sistema multiporte. Potere Pubblico. Stato di San Paolo. Brasile. 



\section{LISTA DE TABELAS}

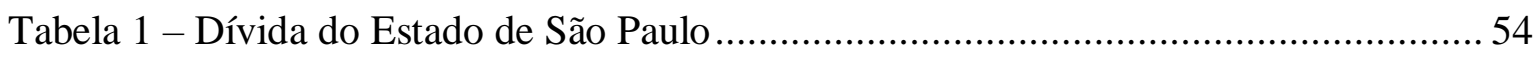

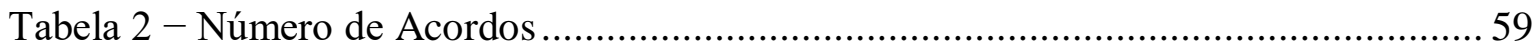

Tabela 3 - Arbitragens do Estado de São Paulo ........................................................... 169

Tabela 4 - Cláusulas Compromissórias dos Contratos do Estado de São Paulo.............. 172

\section{LISTA DE FIGURAS}

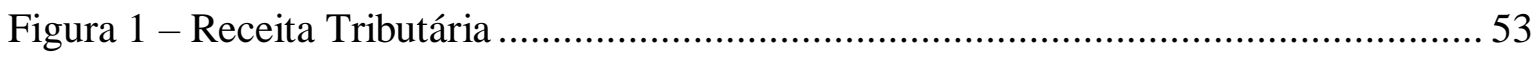

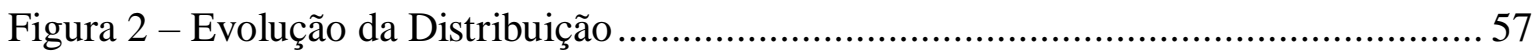

Figura 3 - Evolução do Acervo Processual ................................................................... 58

Figura 4 - Evolução da Distribuição: Capital e Interior................................................. 58

Figura 5 - Evolução do Acervo: Capital e Interior ....................................................... 59

Figura 6 - Dez principais temas de ações contra o Estado de São Paulo em 2019 ............ 71

Figura 7 - Dez principais temas de ações sobre políticas públicas contra o

Estado de São Paulo em 2019 ........................................................................... 73

Figura 8 - Sistema Estadual de Controladoria............................................................... 224 



\section{SUMÁRIO}

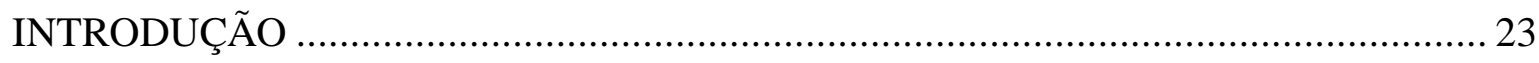

Delimitação do tema e colocação do problema .......................................................... 26

O problema central e a inovação do ponto de vista acadêmico ....................................... 26

Pressupostos para o uso de mecanismos alternativos de solução de controvérsias pela

Fazenda Pública

(i) Previsão legal: existe um microssistema de meios alternativos de solução de controvérsias envolvendo a Fazenda Pública?

(ii) Disponibilidade do direito, transigibilidade e possibilidade de acordos

(iii) Possibilidade dos advogados públicos ou autoridades competentes transigirem ou celebrarem acordos quanto ao método de resolução do conflito

(iv) Adequação do litígio ao modelo escolhido

(v) Vantagens do uso de meios alternativos e adequados de solução de controvérsias pela Fazenda Pública 42

(vi) Limitação do estudo ao contencioso geral, excluindo demandas tributárias ...... 42

A Fazenda Pública do Estado de São Paulo como um grande litigante: compreendendo o contencioso de massa 42

1. Ausência de um contencioso administrativo 43

2. Advento da Constituição de 1988 e a garantia de um amplo acesso à justiça 45

3. Mito da indisponibilidade de direitos e bens públicos, impossibilitando a

Fazenda Pública de celebrar acordos 46

4. Ausência no passado e o não uso de instrumentos de resolução de conflitos em massa, tais como o incidente de resolução de conflitos e o incidente de resolução de demandas repetitivas (IRDR) 47

5. Falta de vontade política, rolagem de dívida e falta de orçamento..... 49

6. Cultura do litígio tanto da advocacia pública como da advocacia privada 


\section{CAPÍTULO 1 - INSERÇÃO DO SISTEMA DE JUSTIÇA MULTIPORTAS NO}

\section{MODELO BRASILEIRO E A POSIÇÃO DA FAZENDA PÚBLICA ...79}

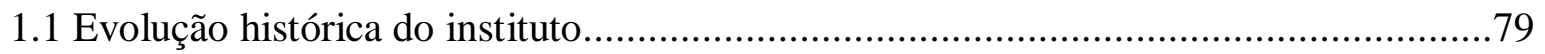

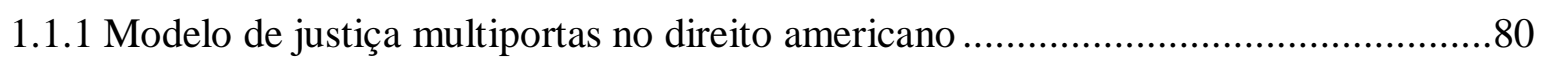

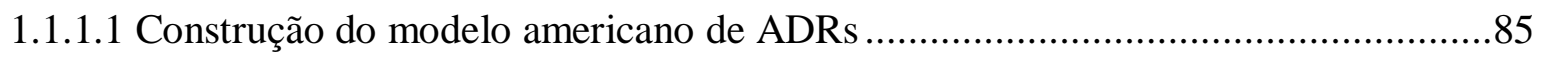

1.1.2 Cenário mundial do movimento de ADRs...........................................................94

1.2 Acesso à justiça e mecanismos de acesso da população nos conflitos em face da

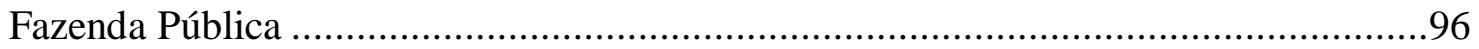

1.2.1 Projeto Florença e acesso à justiça ........................................................................99

1.2.2 Acesso à justiça e o Estado em juízo. Importância da Resolução n. 125 do CNJ ....106

1.3 Modelos de solução de conflitos autocompositivos e heterocompositivos:

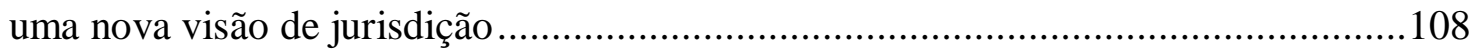

1.3.1 Técnicas de solução de controvérsias...............................................................111

1.3.2 Técnicas de solução de controvérsias básicas ou primárias .................................112

1.3.2.1 Conciliação e Fazenda Pública.......................................................................113

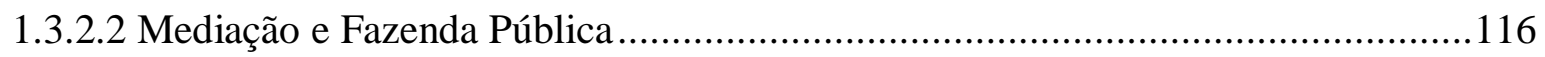

1.3.2.2.1 As diversas concepções de mediação ..........................................................117

1.3.2.2.2 Histórico da mediação no cenário mundial e no Brasil ....................................121

1.3.2.2.3 Mediação como política pública: Resolução n. 125 do CNJ, novo CPC e

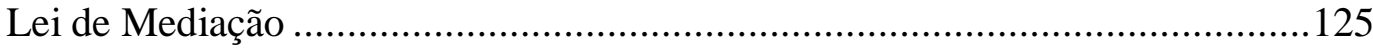

1.3.2.2.4 Princípios e técnicas de mediação e sua utilização prática ...............................128

1.3.2.2.4.1 Mediadores: função e regramento ...............................................................131

1.3.2.2.5 Mediação judicial e a Fazenda Pública ...........................................................132

1.3.2.2.5.1 Adequação e cabimento da mediação em relação à Fazenda Pública .............137 
1.3.2.

1.3.2.2.5.3 Câmaras públicas de conciliação vinculadas aos tribunais ............................ 142

1.3.2.2.5.4 Cejuscs e a participação da Fazenda Pública do Estado de São Paulo ........... 143

1.3.2.2.6 Mediação extrajudicial e a Fazenda Pública ................................................. 147

1.3.2.2.6.1 Câmaras privadas de resolução de conflitos ................................................. 150

1.3.2.2.7 Câmaras de resolução de conflitos da Administração Pública .......................... 152

1.3.2.3 Arbitragem e Fazenda Pública: o modelo do Estado de São Paulo ...................... 153

1.3.2.3.1 Principais características das arbitragens envolvendo o Estado de São Paulo... 157

1.3.2.3.2 Direito aplicável: princípio da legalidade e vedação do uso da equidade........... 158

1.3.2.3.3 A (des)necessidade de previsão em edital ................................................... 158

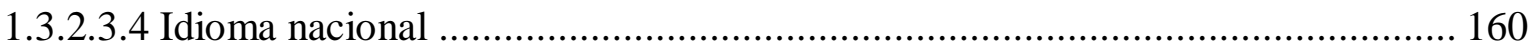

1.3.2.3.5 Publicidade do contrato e da cláusula: vedação da confidencialidade ............... 161

1.3.2.3.6 Algumas características ligadas ao procedimento ......................................... 162

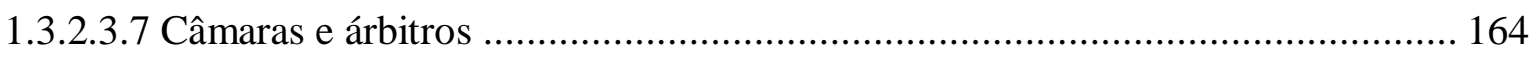

1.3.2.3.8 Arbitragens do Estado de São Paulo ......................................................... 168

1.3.2.3.8 Análise das cláusulas arbitrais em vigor no Estado de São Paulo ..................... 170

1.3.3 Técnicas de solução de controvérsias combinadas ou secundárias ........................ 175

1.3.4 Incidentes de resolução de demandas repetitivas instaurados pelo

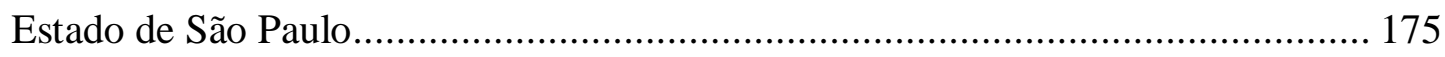

1.3.5 Acordos em processos executivos e precatórios realizados pelo

Estado de São Paulo........................................................................................ 176

1.3.6 Procedimento administrativo de reparação e indenização do Estado de São Paulo. 178

CAPÍTULO II - FAZENDA PÚBLICA E ACORDO ADMINISTRATIVO ................. 183

2.1 Convenções celebradas pela Fazenda Pública .................................................... 183

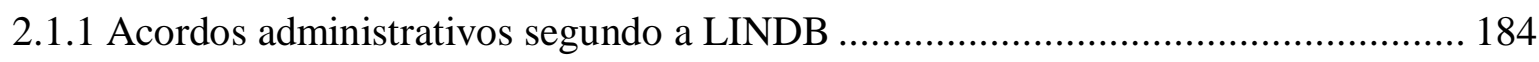


2.1.2 Acordo para estipulação de mecanismos alternativos de solução de controvérsias e

a Fazenda Pública: negócio jurídico entre o direito processual e o administrativo ..189

2.1.2.1 A Fazenda Pública e a vontade administrativa .194

2.1.2.1.1 A fase interna para estipulação de mecanismos alternativos de solução de controvérsias e a Fazenda Pública ....................................................................194

2.1.2.1.2 A vontade e motivação administrativa ...........................................................197

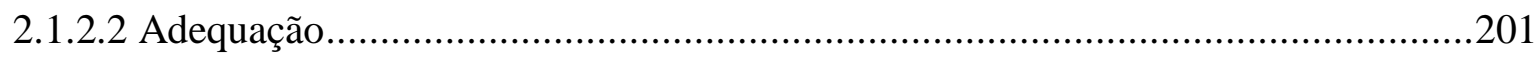

2.1.2.3 Advocacia pública e autoridade competente: manifestação da vontade estatal.....204

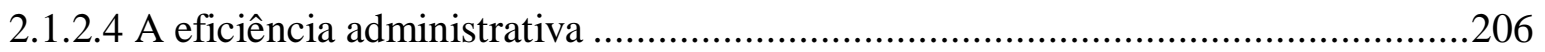

2.1.2.5 Análise econômica do uso de ADR pela Fazenda Pública .................................208

2.1.2.6 Efeitos das cláusulas de ADR nos acordos celebrados pela Fazenda Pública .......215

2.2 Termo de ajustamento de conduta e os acordos administrativos .............................217

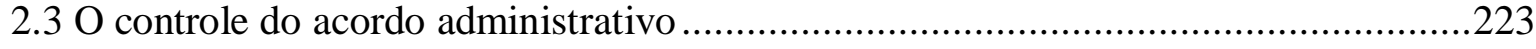

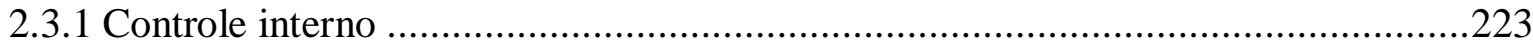

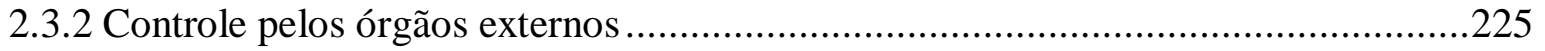

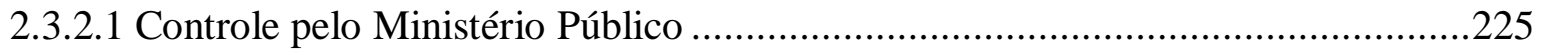

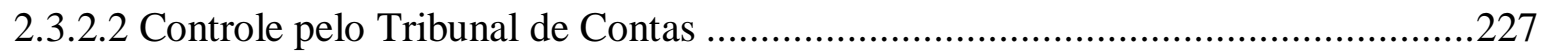

2.4 Acordos de leniência e reparação ao erário .........................................................229

2.4.1 Apresentação e delimitação do tema: os problemas decorrentes dos cartéis e as intervenções nocivas à liberdade de concorrência ............................................2229

2.4.2 Breve análise das origens do modelo de acordo de leniência e o modelo adotado

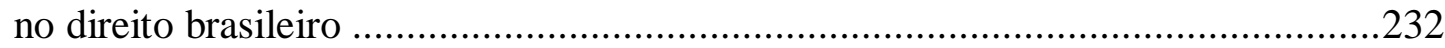

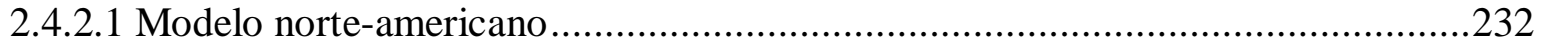

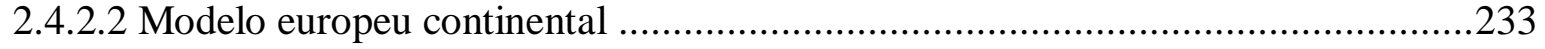

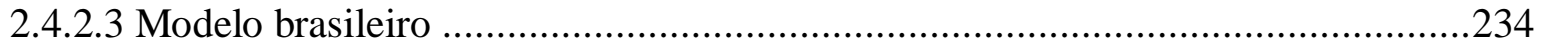

2.4.3 Modelagem do modelo brasileiro: o problema da multiplicidade de agentes de controle 
CAPÍTULO III - NEGOCIAÇÃO E DESENHO DE SOLUÇÃO DE CONTROVÉRSIAS. DISPUTE SYSTEM DESIGN E O PAPEL DA FAZENDA PÚBLICA 245

3.1 Negociação e Fazenda Pública: abrindo mão da superioridade ................................ 245

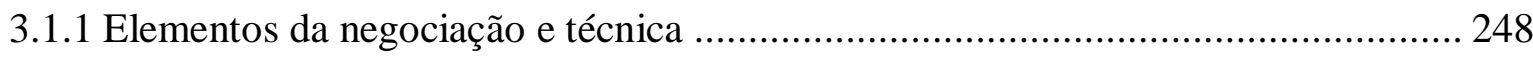

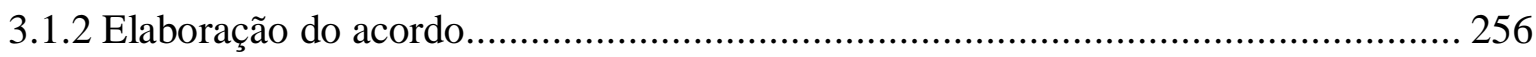

3.1.3 Aplicação institucional da negociação......................................................... 257

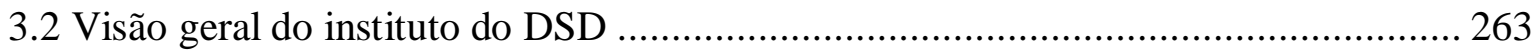

3.2.1 Utilização dos princípios de DSD a partir dos postulados da negociação baseada em interesse - aplicação à Fazenda Pública ........................................................ 268

3.2.2 Processualização: construção do procedimento .................................................. 271

3.2.3 Diagnóstico do conflito: tipologia e adequação .................................................. 272

3.2.4 Propostas para utilização de DSD pela Fazenda Pública ...................................... 273

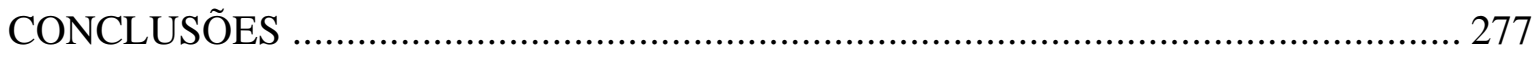

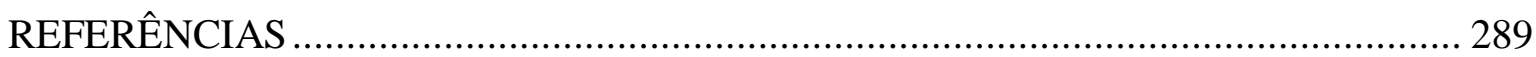





\section{INTRODUÇÃO}

O presente trabalho versa sobre o questionamento do sistema adversarial que a Fazenda Pública adota como forma primordial para solução de seus conflitos e as alternativas possíveis dentro do sistema jurídico, abandonando a ideia binária de oposição Estado-cidadão, com a construção de uma solução de ganho de ambas as partes: seria possível abandonar a fórmula vitória vs. derrota e adotar uma solução ganha ganha?

Dentre as várias transformações ocorridas no direito processual civil brasileiro nas últimas décadas, uma das mais significativas corresponde ao reconhecimento de que a tradicional fórmula de solução de litígios por meio do Poder Judiciário encontra-se em série crise de efetividade, o que se evidencia pela longa duração dos processos, associada ao baixo índice de satisfação e credibilidade. Tais fatos hoje são apontados como problemas estruturais da nossa Justiça.

Do ponto de vista constitucional, o direito pátrio já previa, desde a Constituição de 1946, o direito ao acesso à justiça, mas foi a Constituição de 1988, a chamada "Constituição cidadã", de caráter extensivo, com a positivação das mais diversas gamas de direitos, que previu, no artigo $5^{\circ}$, inciso $\mathrm{XXXV}$, que "a lei não excluirá da apreciação do Poder Judiciário lesão ou ameaça a direito".

Note-se que esse ponto abrange não apenas os direitos já lesados, mas a garantia preventiva de uma futura ameaça de lesão, e que a técnica adotada foi a da realização dos direitos pelo processo judicial. Nesse sentido, a lição de Dinamarco:

É vaga e pouco acrescenta ao conhecimento do processo a usual afirmação de que ele é um instrumento, enquanto não acompanhada da indicação dos objetivos a serem alcançados mediante o seu emprego. Todo instrumento, como tal, é meio; e todo meio só é tal e se legitima, em função dos fins a que se destina. $\mathrm{O}$ raciocínio teleológico há de incluir então, necessariamente, a fixação dos escopos do processo, ou seja, dos propósitos norteadores da sua instituição e das condutas dos agentes estatais que o utilizam. Assim é que se poderá conferir um conteúdo substancial a essa usual assertiva da doutrina, mediante a investigação do escopo, ou escopos em razão dos quais toda ordem jurídica inclui um sistema processual. ${ }^{1}$

1 DINAMARCO, Cândido Rangel. A instrumentalidade do processo. 10. ed. rev. e atual. São Paulo: Malheiros, 2002. p. 181. 
Assim, o processo civil surge na forma hodierna como um mecanismo, uma técnica, um instrumento para a realização do direito, e cumpre um fim. ${ }^{2}$

Portanto, o processo civil judicializado não é um fim em si mesmo, mas uma das ferramentas que o cidadão tem para ter acesso à justiça. Nesse diapasão, compreende-se que o escopo social do processo acaba por abandonar de certa forma a visão individualista do processo civil, eis que ele acaba por ter uma função coletiva, atingindo toda a sociedade. ${ }^{3}$

Ganha importância o tema do acesso à justiça, cujo grande contribuição advém de Mauro Cappelletti:

A expressão "acesso à justiça" é reconhecidamente de difícil definição, mas serve para determinar duas finalidades básicas do sistema jurídico - o sistema pelo qual as pessoas podem reivindicar seus direitos e/ou resolver seus litígios sob os auspícios do Estado que, primeiro deve ser realmente acessível a todos; segundo, ele deve produzir resultados que sejam individual e socialmente justos. ${ }^{4}$

No direito pátrio, juristas como Bedaque, com supedâneo na doutrina de Kazuo Watanabe grande estudioso da matéria, se vale da expressão ordem jurídica justa como forma de tratar o relevante tema do acesso à justiça no direito processual ${ }^{5}$. É nesse cenário de acesso à justiça que o estudo dos mecanismos multiportas de solução de conflitos

\footnotetext{
2 "Tem-se por técnica a predisposição ordenada de meios destinados a obter certos resultados. Toda técnica, por isso, é eminentemente instrumental, no sentido de que só se justifica em razão da existência de alguma finalidade a cumprir e de que deve ser instituída e praticada com vistas à plena consecução da finalidade. Daí a ideia de que todo objetivo traçado sem o aporte de uma técnica destinada a proporcionar sua consecução é estéril; e é cega toda técnica construída sem a visão clara dos objetivos a serem atuados." (DINAMARCO, Cândido Rangel, A instrumentalidade do processo, cit., p. 273-274).

3 "Na criticada visão estritamente jurídica do fenômeno político que é jurisdição, os estudiosos do processo conformaram-se inicialmente com afirmações extremamente individualistas, ligadas ao sincretismo privatista em que o sistema processual aparece como meio de exercício dos direitos e institucionalmente destinado à sua satisfação. Dizia-se, então, que o escopo do processo era a tutela dos direitos, naquela visão pandectista que colocava a ação como centro do sistema e a descrevia como o próprio direito subjetivo em atitude de repulsa à lesão sofrida. Hoje, reconhecida a autonomia da ação e proclamado o método do processo civil de resultados, sabe-se que a tutela jurisdicional é dada às pessoas, não aos direitos, e somente àquele sujeito que tiver razão: a tutela dos direitos não é o escopo da jurisdição nem do sistema processual; constitui grave erro de perspectiva a crença de que o sistema gravite em torno da ação ou dos direitos subjetivos materiais." (DINAMARCO, Cândido Rangel, A instrumentalidade do processo, cit., p. 184 , grifo nosso).

${ }^{4}$ CAPPELLETTI, Mauro; GARTH, Bryant. Acesso à justiça. Tradução: Ellen Gracie Northfleet. Porto Alegre: Sergio Antonio Fabris Editor, 1988. p. 3.

5 “Acesso à justiça, ou mais propriamente, acesso à ordem jurídica justa, significa proporcionar a todos, sem qualquer restrição, o direito de pleitear a tutela jurisdicional do Estado e de ter à disposição o meio constitucionalmente previsto para alcançar esse resultado. Ninguém pode ser privado do devido processo legal, ou, melhor, do devido processo constitucional. É o processo modelado em conformidade com garantias fundamentais, suficientes para torná-lo équo, correto, justo." (BEDAQUE, José Roberto dos Santos. Tutela cautelar e tutela antecipada: tutelas sumárias e de urgência: (tentativa de sistematização). 3. ed., rev. e ampl. São Paulo: Malheiros, 2003. p. 71).
} 
estabelecidos entre a Fazenda Pública e o cidadão se mostra de suma importância. Aponta Kazuo Watanabe que problema está em se encontrar uma solução justa, tempestiva e adequada. $^{6}$

Associa-se a esse panorama o tratamento legislativo pátrio que, por meio do novo Código de Processo Civil (CPC), a Lei de Mediação e a Lei de Arbitragem, constituiu um quadro de possibilidades de múltiplas portas que, no conceito de Frank Sander, são as chamadas técnicas básicas de solução de controvérsias ${ }^{7}$. Dessa forma, do ponto de vista legal, já existe um arcabouço que permite a utilização de tais métodos.

Vale lembrar a Resolução n. 125 do Conselho Nacional de Justiça (CNJ), que instituiu a "política judiciária nacional de tratamento dos conflitos de interesses, tendente a assegurar a todos o direito à solução dos conflitos por meios adequados à sua natureza e peculiaridade". E mais, o parágrafo único do seu artigo $1^{\circ}$ estabelece:

Parágrafo único. Aos órgãos judiciários incumbe, nos termos do art. 334 do Novo Código de Processo Civil combinado com o art. 27 da Lei de Mediação, antes da solução adjudicada mediante sentença, oferecer outros mecanismos de soluções de controvérsias, em especial os chamados meios consensuais, como a mediação e a conciliação, bem assim prestar atendimento e orientação ao cidadão. (Redação dada pela Emenda no 2, de 08.03.16).

Além disso, a reforma da Lei de Introdução às Normas do Direito Brasileiro (LINDB), realizada pela Lei n. 13.655/2018, introduziu o novel artigo 26, um verdadeiro marco legal para acordos administrativos, que estabeleceu duas possibilidades para a estipulação de acordos, a escolha de mecanismos alternativos de solução de controvérsias ou o acordo resolutivo da própria controvérsia. ${ }^{8}$

\footnotetext{
6 "Quando se trata de solução adequada dos conflitos de interesses, insisto em que o preceito constitucional que assegura o acesso à Justiça traz implicitamente o princípio da adequação; não se assegura apenas o acesso à Justiça, mas se assegura o acesso para obter uma solução adequada aos conflitos, solução tempestiva, que está bem adequada ao tipo de conflito que está sendo levado ao Judiciário." (WATANABE, Kazuo. Modalidade de mediação. In: DELGADO, José et al. Mediação: um projeto inovador. Brasília: Centro de Estudos Judiciários, CJF, 2003. p. 46).

${ }^{7}$ SANDER, Frank E. A. The multi-door courthouse: settling disputes in the year 2000. Barrister, ABA Young Lawyers Division, v. 3, No. 18, Summer 1976.

${ }^{8}$ Lei n. 13.655/2018: “Art. 26. Para eliminar irregularidade, incerteza jurídica ou situação contenciosa na aplicação do direito público, inclusive no caso de expedição de licença, a autoridade administrativa poderá, após oitiva do órgão jurídico e, quando for o caso, após realização de consulta pública, e presentes razões de relevante interesse geral, celebrar compromisso com os interessados, observada a legislação aplicável, o qual só produzirá efeitos a partir de sua publicação oficial. (Incluído pela Lei n ${ }^{\circ}$ 13.655, de 2018).”
} 
Por tudo isso, o tema é relevante ao aperfeiçoamento do sistema multiportas de solução de conflitos envolvendo a Administração Pública e, embora tenha trato multidisciplinar, eis que envolve uma gama de ramos do direito, tal qual o direito constitucional e o direito administrativo, é justamente sob o enfoque processual que se pretende levar a cabo este estudo.

\section{Delimitação do tema e colocação do problema}

\section{O problema central e a inovação do ponto de vista acadêmico}

O modelo tradicional desenvolvido no sistema brasileiro de solução de controvérsias impõe um peso muito grande nas mãos do Judiciário, tratando-o como mecanismo quase único de solução de litígios. Note-se que nesse modelo a solução é imposta e não negociada. ${ }^{9}$

Ao classificar as formas de solução de litígios, pode-se observar nitidamente a existência de dois modelos: um autocompositivo, no qual as partes, entre si ou por meio de um terceiro facilitador, chegam a uma solução, a exemplo da negociação, da conciliação, da avaliação de terceiro neutro, do med-arb e do mini-trail, por exemplo. De outro, temos sistemas em que um terceiro impõe a decisão: aqui se situam a arbitragem ${ }^{10}$ e a jurisdição estatal. $^{11}$

Mesmo na arbitragem, embora um terceiro (ou painel arbitral) imponha a decisão, há negociação, ou acordo, quando da opção por esse sistema. Daí dizer-se que a

\footnotetext{
${ }^{9}$ WATANABE, Kazuo. Política pública do Poder Judiciário nacional para tratamento adequado dos conflitos de interesses. Disponível em: https://www.tjsp.jus.br/Download/Conciliacao/Nucleo/ParecerDesKazuoWatanabe.pdf. Acesso em: 07 maio 2019.

${ }^{10}$ Carlos Alberto Carmona assim conceitua arbitragem: "A arbitragem - meio alternativo de solução de controvérsias através da intervenção de uma ou mais pessoas que recebem seus poderes de uma convenção privada, decidindo com base nela, sem intervenção estatal, sendo a decisão destinada a assumir a mesma eficácia da sentença judicial - é colocada à disposição de quem quer que seja, para solução de conflitos relativos a direitos patrimoniais acerca dos quais os litigantes possam dispor." (CARMONA, Carlos Alberto. Arbitragem e processo: um comentário à Lei n. 9.307/96. 2. ed., rev., atual. e ampl. São Paulo: Atlas, 2004. p. 51).

${ }^{11}$ Nesse sentido: LORENCINI, Marco Antonio Garcia Lopes. "Sistemas multiportas": opções para o tratamento de conflitos de forma adequada. In: SALLES, Carlos Alberto de; LORENCINI, Marco Antônio Garcia Lopes; SILVA, Paulo Eduardo Alves da (coord.). Negociação, mediação e arbitragem: curso básico para programas de graduação em direito. Rio de Janeiro: Forense, São Paulo: Método, 2012. p. 57-85.
} 


\section{CONCLUSÕES}

O presente trabalho procurou levantar questionamentos acerca da adoção do sistema adversarial que a Fazenda Pública acabou por impor como forma principal para solução de seus conflitos. Procurou-se demonstrar que as alternativas possíveis dentro do sistema jurídico já existem, e passam antes de tudo pelo abandono da ideia binária de oposição Estado-cidadão, partindo-se para um modelo de construção de solução com ganho de ambas as partes

Os dados aqui expostos mostram a realidade do contencioso do Estado de São Paulo, decorrente da adoção da política de resolução de conflitos quase que exclusivamente pelo Judiciário, que, a par da existência de uma política tímida de não interposição de recursos aos tribunais de justiça e superiores em matérias cujas derrotas são constantes, o número de ingresso de novas ações torna o sistema absolutamente inviável. A conta é simples: o Estado de São Paulo, no ano de 2019, deixou de interpor cerca de 15 mil recursos, num universo de cerca de 320 mil novas ações no ano de 2018 e de cerca de 400 a 500 mil novas ações no ano de 2019, cujo número oficial ainda não foi divulgado.

A Fazenda Pública do Estado de São Paulo, ainda que forçosamente apta pela legislação pátria ao emprego de mecanismos alternativos de solução de controvérsias, ainda sofre pela absoluta falta de gerenciamento de seu contencioso.

Os números do Estado de São Paulo demonstram isso pois, ainda que gritante o número de novas ações e de derrotas por uma jurisprudência muitas vezes consagrada, sobretudo em áreas como direitos trabalhistas e estatutários de servidores públicos, saúde pública e pagamentos de toda ordem, há absoluta falta de vontade política em se gerenciar o contencioso, culminando com uma política nefasta de consecutivas derrotas, recursos judiciais protelatórios e pagamento de precatórios.

E mais, a fim de "empurrar o problema" para outras gestões e gerações, optou-se recentemente por diminuir o valor das OPVs, para permitir o pagamento por meio de precatórios, em futuras gestões. O efeito prático é que muitos credores morrem ou cedem 
seus direitos creditórios para empresas de comércio de precatório, com deságio de até cinquenta por cento.

A despeito da total falta de respeito pelo sistema de justiça, pela cidadania e pelo fim social do processo civil, a atual prática de resolver os problemas jurídicos do Estado de São Paulo por meio da ação judicial e pela rolagem da dívida por meio de precatórios, vem gerando um prejuízo econômico ao Estado.

É possível apurar economicamente, por meio de fórmula matemática, quando o acordo se mostra mais vantajoso à Administração, ao invés do processo. O cálculo envolve o custo do processo, o tempo do processo e as chances de vitória ou derrota. Não se nega, entretanto, a importância da normatização de procedimentos internos de processualização da tomada de decisão quanto ao uso de meios alternativos de solução de controvérsias pela Administração.

Especificamente no caso do Estado de São Paulo, embora não sejam divulgados os números oficiais exatos das derrotas do contencioso, é cediço que, pelo grande número de processos em execução, o modelo atual não é bem-sucedido. Somente no ano de 2019, ingressaram no setor de execuções cerca de 67 mil novos processos. Tais processos, que decorrem do trânsito em julgado de processos de conhecimento de anos anteriores lembrando que em 2014, entraram 55.544 processos novos; em 2015, 64.972; em 2016, 122.938; em 2017, 235.062; em 2018, bateu-se o recorde, com 319.576, o que indica que o número provável do ano de 2019 passará de 500 mil processos novos -, associados à redução do limite de pagamento por OPV, mostram que se avizinha uma grave crise de pagamentos aos credores.

Diante dessa triste realidade, na qual a solução primordial dos conflitos se dá por meio da sentença judicial, o estudo da aplicação de meios alternativos de solução de controvérsias, como a negociação, a conciliação e a mediação, é imperioso. Porém, a realidade evidencia que a opção adotada pela Fazenda Pública pela sentença judicial, associada às sucessivas derrotas, bem como a manutenção dessa qualidade de litigante de massa, ainda que inconsciente, é inconsequente, pouco se importando com o custo do processo, o custo social e o prejuízo econômico que causa à população e ao erário. 
Mecanismos jurídicos aptos a repensar o sistema, conforme exposto, estão plenamente em vigor e podem ser utilizados pelo Estado de São Paulo. Necessita-se, contudo, de uma verdadeira mudança de mentalidade, e mais, de um verdadeiro gerenciamento do contencioso, abrindo as portas aos acordos.

O direito processual civil brasileiro vem mudando nas últimas décadas, e uma das mais significativas alterações corresponde ao reconhecimento de que a adoção de um sistema de soluções alternativas de controvérsias, ao invés da tradicional fórmula de solução de litígios por meio do Poder Judiciário, pode implicar um ganho social. Tal modelo aplica-se à Fazenda Pública.

Não se nega que já existe a previsão legal de tal sistema, pois, por meio do novo CPC, da Lei de Mediação e da Lei de Arbitragem, constituiu-se um quadro de possibilidades de múltiplas portas, no conceito de Frank Sander. Dessa forma, do ponto de vista legal, já existe um arcabouço que permite a utilização de tais métodos.

Outro importante incentivo aos meios alternativos de solução de controvérsias partiu do próprio Judiciário que, por meio a Resolução n. 125 do CNJ, instituiu a "política judiciária nacional de tratamento dos conflitos de interesses, tendente a assegurar a todos o direito à solução dos conflitos por meios adequados à sua natureza e peculiaridade", reconhecendo a necessidade de se cultivas novas formas de resolução de conflitos.

No que tange à Fazenda Pública, a reforma da LINDB, realizada pela Lei n. 13.655/2018, introduziu o novel artigo 26, um verdadeiro marco legal para acordos administrativos. Entende-se que os acordos são de duas ordens: a escolha de mecanismos alternativos de solução de controvérsias ou o acordo resolutivo da própria controvérsia.

No modelo atual a jurisdição estatal, meio pelo qual o poder estatal se exerce, é quase que exclusivamente o grande solucionador de conflitos e pacificador social. Porém, num cenário como o de enfrentamento de milhares ações envolvendo a Fazenda Pública, a multiplicidade de temas, bem como a falta de estrutura para dar conta de cerca de 400 mil novos processos anuais, tornou o sistema inadequado para dar uma resposta social. 
Discutiu-se porque o Estado de São Paulo, ente federativo mais rico e desenvolvido, com a estrutura tecnológica mais avançada, o maior número de advogados, juízes e faculdades de direito, tem índices tão baixos de acordos administrativos e como seu contencioso aumenta em número alarmante.

Demonstrou-se que os meios alternativos de solução de controvérsias não são aplicados, senão a arbitragem, justamente por uma imposição do mercado.

Num cenário de múltiplas opções postas à disposição da Administração, deve haver no mínimo algum balizamento legal para que as escolhas possam ser feitas com segurança jurídica e sem eventuais questionamentos por órgão de accountability.

Rememorando o arcabouço jurídico que se mostra alternativo à sentença judicial, podemos apontar hipóteses em que o legislador autorizou o uso pela Administração da conciliação, da mediação e da arbitragem. Mas, de qualquer modo, ao se analisar a Lei dos Juizados Especiais da Fazenda Pública, o novo CPC, a Lei de Mediação e a Lei de Arbitragem, é nítida a permissão de uso por parte da Administração Pública desses mecanismos alternativos à sentença judicial. Tal discussão já foi amplamente veiculada na doutrina, quando o embate ocorria no cenário da utilização da arbitragem pela Administração Pública. Ademais, o novel artigo 26 da LINDB traz uma verdadeira autorização genérica para acordos. Dessa forma, proteção legislativa e segurança jurídica já existem em nosso ordenamento.

Por ora, atenta-se a uma doutrina que tenta classificar direitos aptos a algum grau de acordo com a Administração Pública conforme sua natureza: direitos patrimoniais, direitos transmissíveis, direitos disponíveis e direitos envolvendo a contratualidade administrativa. Há ainda a clássica divisão da disponibilidade e, portanto, a possibilidade de acordos, segundo se tratar de interesses primários ou secundários da Administração. Porém, no que tange à mediação, o legislador superou a questão, eis que mesmo direitos indisponíveis, porém transigíveis, podem ser objeto de tal mecanismo.

Concluiu-se que a doutrina administrativista vem buscando analisar o direito em disputa quanto à sua natureza para, a partir daí, classificá-lo quanto à possibilidade de transação ou acordo. Sob essa perspectiva, é impossível a formação de um modelo único 
que permitisse compreender a suscetibilidade dos litígios à composição por meio de "acordos". Importante inovação legislativa veio com a Lei de Mediação, ao conferir à advocacia pública importante papel nos acordos, mostrando que ao representante legal da Administração Pública federal foi reservado o papel central nos atos de disposição do Estado. Daí se compreender a dimensão que a advocacia pública ganha, ao se tornar o grande propulsor de alternativas à jurisdição estatal, na solução de controvérsias com a Administração.

Defendeu-se o uso do critério da adequação, para determinar a utilização de métodos alternativos de solução de controvérsias pela Administração Pública. Pode-se determinar que, no cenário atual, a conciliação, a mediação e a arbitragem começam a ter espaço para determinados tipos de litígios. Para tanto, necessário haver algum grau de processualização pela Administração, em expediente interno para escolha, que deve seguir os parâmetros da boa administração. Tal procedimento deve ser transparente e público, para deixar claro quais os caminhos intelectuais perseguidos pelo administrador, permitindo que toda a sociedade civil possa exercer a accountability.

Algumas críticas foram levantadas para demonstrar porque o contencioso da Fazenda Pública chegou aos atuais níveis de litigiosidade. O atual modelo de jurisdição una no Brasil não é uma novidade e se baseia na importação do modelo lusitano. Não é de se estranhar que, ao lado da experiência da arbitragem, em que se costuma falar de uma verdadeira jurisdição arbitral e a justiça desportiva constitucionalmente prevista, pouco espaço é encontrado para um segundo sistema de justiça obrigatório, senão o estatal.

Além disso, com o advento da Constituição de 1988, foi garantido um amplo acesso à justiça, aos brasileiros e aos estrangeiros residentes no País, a inviolabilidade do direito à vida, à liberdade, à igualdade, à segurança e à propriedade e garantias individuais. Tal fato gerou a judicialização desses direitos frente à Administração Pública.

Ressalta-se ainda que o mito da indisponibilidade de direitos e bens públicos, impossibilitando a Fazenda Pública de celebrar acordos, é enraizado na Administração Pública e nos gestores, fazendo com que não se transija, não se abra mão de quase nenhum direito, senão pela vontade judicial. 
Outra causa apontada foi a ausência, no passado, de instrumentos de resolução de conflitos em massa, tais como o incidente de resolução de conflitos e o incidente de resolução de demandas repetitivas (IRDR). Conforme se demonstrou pelos números do contencioso geral do Estado de São Paulo, no ano de 2019, provavelmente se chegará à cifra de 1,1 milhões de processos acumulados. A tradicional forma de se litigar, até o advento da Lei n. 7.437/85, em um contencioso de massa tradicionalmente previsto, era o litisconsórcio multitudinário. Tal forma, em relação aos particulares, foi mantida, sobretudo visando à fixação de honorários advocatícios. Isso, contudo, mudou de certa forma, eis que agora, em sede de execução, foi prevista a possibilidade de honorários em execução individual, decorrente da aplicação da Súmula n. 345 do STJ

Outro aspecto que impediu uma solução mais breve, ou mesmo administrativa, de litígios, ou por meios alternativos de solução de controvérsias, foi a possibilidade de rolar a dívida por meio de precatórios. Note-se que tal prática na administração pública brasileira já vem se consolidando em todas as esferas, seja municipal, estadual ou federal.

Por fim, não se nega a cultura do litígio, tanto da advocacia pública como da advocacia privada, aprendida nas faculdades, de submeterem conflitos ao método binário do ganha-perde, imposto pelo contencioso judicial. Há, portanto, uma falta de aprendizado quanto à possibilidade das partes se submeterem a métodos alternativos de solução de controvérsias.

Demonstrou-se a origem do instituto das multiportas, eis que modelo norteamericano importado pelo Brasil, fundamentalmente calcado na teoria de Frank Sander. Baseados no federalismo norte-americano, cada Estado federal pode estabelecer regras de solução de conflitos, sendo comumente citados, no campo das ADRs (ou MASCs no Brasil), os Estados da Flórida e de Nova York como possuidores dos modelos mais evoluídos.

Historicamente, o presente trabalho retomou o acesso à justiça, movimento surgido no pós-Segunda Guerra Mundial, sobretudo com os estudos de Mauro Cappelletti e Bryant Garth, que capitanearam o Projeto Florença. Ele é encarado como um movimento social, mas a expressão acesso à justiça tem interpretações que vão além da sociologia jurídica, inspirando inclusive análises econômicas do direito. Em se tratando de verdadeiro 
movimento mundial, a pesquisa envolveu a contribuição de diversas culturas jurídicas, ganhando força no Brasil com a Constituição de 1988.

A conciliação envolvendo a Fazenda Pública se aproxima do conceito de acordo, seja celebrado no curso de um processo, seja numa fase anterior à propositura da demanda, mas sem sombra de dúvida impõe às partes concessões recíprocas e uma finalidade negocial.

No direito brasileiro, o novo CPC procurou dar um tratamento diferenciado às funções dos conciliadores e dos mediadores, porém a conciliação e a mediação acabam por, do ponto de vista de resultado, sendo o mesmo instituto, sobretudo sob a visão da doutrina americana. A mediação é em geral definida como um meio de solução de conflitos em que um terceiro facilitador auxiliar as partes a solucionarem seu conflito. Assim, existe a figura de um terceiro, com especial função de levar as partes a um acordo. É, portanto, um método cooperativo, em que as partes chegam por si a um acordo, mas com o auxílio de um terceiro. O primeiro discrímen é a existência de vínculo entre as partes: na conciliação, não existe tal vínculo ( $v . g$. numa batida de carro), na mediação ele existe ( $v . g$ como em questões familiares). Uma segunda diferenciação dos institutos reside na postura e técnica adotada no procedimento: na conciliação, o terceiro facilitador sugere soluções para o conflito; por sua vez, na mediação, tendo em vista o vínculo preexistente, o terceiro facilitador tem como dever auxiliar as partes a entenderem por si mesmas o conflito; dessa forma, partindo da autocompreensão do conflito, cabe ao mediador facilitar a comunicação entre as partes, de maneira que elas encontrem a solução por si próprias

Para a Administração Pública negociar num ambiente de mediação, deve haver um maior grau de consensualismo administrativo. Para tanto, é necessário repensar o modelo de supremacia da Administração em relação ao particular e enfrentar dogmas como os da "indisponibilidade de bens e direitos" e da "estrita legalidade" como impeditivos da realização de acordos.

Deve-se reconhecer a possibilidade de que tanto a sociedade como a Administração Pública, aqui vista como mais um dos agentes sociais, devem se unir pelo bem comum e não se colocar numa posição de confronto. O modelo teórico pelo qual isso é possível advém da chamada administração por acordos, na qual há um maior grau de participação e 
colaboração social nos destinos do Estado. Por conta disso, o fenômeno da contratualização da Administração Pública ganha relevo e isso reflete inclusive nos modelos de solução de conflitos.

A Lei de Mediação mostra-se afinada com um novo pensamento administrativo, pois trata o Estado tanto como parte na mediação, tomando partido em um mecanismo ágil e que ainda reduz o sentimento de injustiça do cidadão, quanto permite que a Administração Pública seja um verdadeiro mediador de conflitos, por meio da constituição de câmaras, resolvendo os conflitos entre os demais órgãos e o cidadão. Pode-se, portanto, tratá-la como mais uma face do consensualismo

A arbitragem pode ser considerada como o modelo alternativo de controvérsias pioneiro utilizado pelo Estado de São Paulo, tendo sido empregado mais por uma pressão do mercado, ante um cenário de aumento de complexidade das demandas estatais, sobretudo nos contratos de PPP e de financiamento de infraestrutura. Através desse mecanismo, buscavam-se soluções rápidas e especializadas, ainda que de custo elevado. Pode-se, dessa forma, definir que foram utilizados para o contencioso estratégico.

O direito administrativo brasileiro vem passando por grandes transformações, a partir do prisma da consensualidade, o que vem, de certo, abalando os antigos dogmas da legalidade estrita e da supremacia do interesse público sobre o particular. Um novo marco legal surgiu a partir da Lei n. 13.655/2018, que trata da alteração da LINDB presente no CC de 2002, mas já existente no CC de 1916 como norma de introdução (LICC), e nitidamente reconhecida como uma sobrenorma de todo o direito pátrio.

Defendeu-se que havendo escolha por parte da Administração Pública de mecanismo alternativo de solução de controvérsia por cláusula a ser inserida em contrato, não se pode negar que esse acordo seja um negócio jurídico pré-processual típico, eis que possui previsão legal, atendendo assim à tipicidade, pois tanto a Lei de Mediação como a Lei de Arbitragem preveem a cláusula a ser estipulada pelas partes.

Do ponto de vista da segurança jurídica, em tese, a existência de norma regulamentadora da fase interna em que Administração Pública decide pelo uso de meios alternativos de solução de controvérsia traria tanto para sociedade, capaz de observar como 
age o administrador, quanto para o próprio agente, que não correria o risco de extravasar seus poderes, um maior grau de segurança jurídica e transparência.

Vale lembrar que os acordos administrativos já estavam presentes no direito brasileiro, e os antecedentes dizem respeito aos TACs, referidos na legislação como compromissos de ajustamento de conduta, dão conta de sua inexistência na redação original da Lei da Ação Civil Pública de 1985. Com o advento do ECA em 1990, esse instrumento surgiu no artigo 211, mas somente com o artigo 113 do CDC efetivamente o TAC foi introduzido, com a reforma do artigo $5^{\circ}$, parágrafo $6^{\circ}$, da Lei n. 7.347/85.

Em se tratando de matéria afeta ao direito público, os mecanismos de controle da Administração são plenamente aplicáveis aos acordos administrativos, para a escolha de mecanismo alternativo de solução de controvérsia.

Assim, o controle interno da Administração Pública e a sujeição a diferentes órgãos e esferas de controle externo também devem estar presentes, sobretudo por se tratar de mecanismos consensuais e com maiores margens de questionamentos dos atos e procedimentos pelos quais a Administração Pública realiza o acordo.

Outa forma de acordo diz respeito à Lei de Acordos de Leniência. O fenômeno da formação de cartéis não é algo novo no cenário econômico mundial, tem sua origem na construção de grandes conglomerados econômicos no período posterior à segunda grande revolução industrial e decorre da concentração de mercados de produção ou de serviços, em que empresas atuam como se fossem apenas uma: é o chamado falso oligopólio, em que se dá a aparência de que várias empresas atuam de forma independente, mas há a sombra, em que acordos são celebrados de forma não aparente, entre os diversos players, para controlar o mercado.

Os males desse tipo de atuação são conhecidos: impedem a concorrência do pequeno produtor, há controle do preço afetando os consumidores finais, imposição de políticas aos mercados nacionais, prejuízo à inovação tecnológica e efeitos sobre a concentração do mercado de trabalho, dentre outros. O Brasil pôde experimentar os malefícios de tais práticas. 
Da forma como a legislação trata o tema, restam diversas formas de questionamento da validade dos acordos de leniência celebrados. De certo, o tema passa obrigatoriamente pela separação de poderes e quais os limites reservados constitucionalmente para cada poder, e até onde cada instituição pode agir.

Pode-se concluir que esse grau de insegurança jurídica, decorrente das incertezas impostas pela legislação e, por que não, pela Constituição, podem comprometer importante trabalho que vem sendo feito no combate aos cartéis e ao livre desenvolvimento do mercado.

Uma alternativa dentro do sistema jurídico brasileiro seria a previsão constitucional desse instituto, trazendo os balizamentos e limites de participação de cada instituição. Assim, estariam de certa forma asseguradas a forma e as competências, evitando-se assim questionamentos e conferindo um maior grau de segurança jurídica ao instituto

Da mesma forma, defendeu-se a possibilidade de acordos administrativos em improbidade administrativa. Conforme demonstramos, a cláusula geral de acordos do artigo 26 da LINDB permitiria a celebração de acordo em ação de improbidade. Um primeiro argumento seria o da revogação, por parte da Lei de Mediação, do artigo 17, parágrafo $1^{\circ}$, da Lei de Improbidade, que proíbe acordos que tenham essa temática.

Dessa forma, o campo para o acordo, conforme defendido, está permitido, sendo plenamente possível a celebração. Para tanto, deveria haver uma processualização do rito procedimental para celebrar o acordo, o que é possível mediante o uso da Lei estadual de Processo Administrativo, e de se ater tanto aos parâmetros da Lei de Mediação quanto da LINDB.

Respeitados tais limites, e havendo tese consolidada nos acordos substitutivos/suspensivos das sanções administrativas, como visto em relação às agências reguladoras, sobretudo da União, perfeitamente possível o estabelecimento de um rito e limites para a celebração da avença. 
Não se nega que seria salutar a existência de um decreto regulamentador, tal qual nos acordos de prevenção de dano já tratados, porém a inexistência de tal decreto não impede a realização dos acordos já liberados pelas outras normas citadas.

Por fim, os dados apresentados no presente trabalho demonstram como a judicialização entre a Fazenda Pública e os cidadãos vem aumentando a cada dia. Buscase, por meio do uso de mecanismos alternativos, que essa processualização diminua. Já demonstramos que a conciliação, a mediação e a arbitragem podem ser mecanismos de solução adequados para determinados litígios, afastando assim a decisão do Judiciário.

Para tanto, o estabelecimento de acordos administrativos passa a ser uma importante ferramenta, seja para a determinação do meio alternativo a ser utilizado, seja para a resolução do próprio conflito.

Pode-se ainda valer-se da negociação direta e da criação de desenhos de solução de disputas. Para o uso desses mecanismos, defenderam-se regras mais claras para autorizar os entes públicos a celebrar acordos e transacionar; criação de câmaras de controvérsias envolvendo a Administração; uso da lei de processo administrativo para reparação de danos com orçamento próprio. 



\section{REFERÊNCIAS}

ALEXANDRINO, Marcelo; PAULO, Vicente. Resumo de direito administrativo descomplicado. São Paulo: Método, 2008.

ALMEIDA, Fernando Dias Menezes de. Atos administrativos normativos: algumas questões. In: MEDAUAR, Odete; SCHIRATO, Vitor Rhein (org.). Os caminhos do ato administrativo. São Paulo: Revista dos Tribunais, 2011. p. 219-236.

ALMEIDA, Fernando Dias Menezes de. Contrato administrativo: teoria do contrato administrativo e seu regime jurídico específico. São Paulo: Quartier Latin, 2012. Cap. 4, p. 171-232.f

ALMEIDA, Rafael Alves de; ALMEIDA, Tania; CRESPO, Mariana Hernandez (org.). Tribunal multiportas: investindo no capital social para maximizar o sistema de solução de conflitos no Brasil. Rio de Janeiro: Editora FGV, 2012. Disponível em: https://bibliotecadigital.fgv.br/dspace/bitstream/handle/10438/10361/Tribunal\%20Multipor tas.pdf. Acesso em: 16 dez. 2019.

ALVES, Marcus Vinicius Armani. 2016. 257 p. A Fazenda Pública na arbitragem. Dissertação (Mestrado em Direito) - Faculdade de Direito da Universidade de São Paulo, São Paulo, 2016.

AMARAL, Paulo Osternack. Arbitragem e administração pública: aspectos processuais, medidas de urgência e instrumentos de controle. Belo Horizonte: Fórum, 2012.

ASPERTI, Maria Cecília de Araújo. Meios consensuais de resolução de disputas repetitivas: a negociação, a mediação e os grandes litigantes do Judiciário. 2014. 186 p. Dissertação (Mestrado) - Faculdade de Direito da Universidade de São Paulo, São Paulo, 2014.

BEDAQUE, José Roberto dos Santos. Tutela cautelar e tutela antecipada: tutelas sumárias e de urgência: (tentativa de sistematização). 3. ed., rev. e ampl. São Paulo: Malheiros, 2003.

BERGAMASCHI, André Luis. Resolução de conflitos envolvendo a administração pública por mecanismos consensuais. 2015. 290 p. Dissertação (Mestrado em Direito Processual) - Faculdade de Direito, Universidade de São Paulo, São Paulo, 2015.

BONIZZI, Marcelo José Magalhães. Arbitragem e Estado: ensaio sobre o litígio adequado. Revista de Arbitragem e Mediação, São Paulo, Revista dos Tribunais, v. 12, n. 45, p. 155 174, abr.jun. 2015.

BONIZZI, Marcelo José Magalhães. Breve análise sobre a arbitragem em conflitos que envolvem o Estado. Revista da Procuradoria Geral do Estado de São Paulo, v. 75, p. 1320, jan./jun. 2012. 
BONIZZI, Marcelo José Magalhães. Proporcionalidade e processo: a garantia constitucional da proporcionalidade, a legitimação do processo civil e o controle das decisões judiciais. São Paulo: Atlas, 2006.

BRAGA NETO, Adolfo. Alguns aspectos relevantes sobre a mediação de conflitos. In: GRINOVER, Ada Pellegrini; WATANABE, Kazuo; LAGRASTA NETO, Adolfo (coord.). Mediação e gerenciamento do processo: revolução na prestação jurisdicional: guia prático para a instalação do setor de conciliação e mediação. 2. reimpr. São Paulo: Atlas, 2008.

BUENO, Cassio Scarpinella. Novo Código de Processo Civil anotado. 2. ed. rev., atual. e ampl. São Paulo: Saraiva; 2016.

BUGARIN, Paulo Soares. O princípio constitucional da eficiência: um enfoque doutrinário multidisciplinar. Revista do Tribunal de Contas da União, Brasília, v. 32, n. 87, p. 39-50, jan./mar. 2001.

CAHALI, Francisco José. Curso de arbitragem: Resolução CNJ 125/2010: mediação e conciliação. 2. ed. rev., atual. e ampl. São Paulo: Revista dos Tribunais, 2012.

CÂMARA DE COMÉRCIO INTERNACIONAL (ICC). Regulamento de Mediação. Paris: ICC, 2015. Disponível em: http://cbar.org.br/site/wp-content/uploads/2012/05/ICC-865-1POR-Arbitragem-Mediacao.pdf. Acesso em: 10 out. 2019.

CÂMARA, Flávia; GUIMARÃES, Leonardo. Dispute board: o método de solução de conflitos que vem ganhando espaço no Brasil. Migalhas, de 24 ago. 2018. Disponível em: https://www.migalhas.com.br/dePeso/16,MI286212,21048-

Dispute+board+o+metodo+de+solucao+de+conflitos+que+vem+ganhando. Acesso em: 30 nov. 2019.

CAMPOS, Diogo Leite de. A arbitragem voluntária, jurisdição típica do estado-dosdireitos e dos-cidadãos. In: CAMPOS, Diogo Leite de; MENDES, Gilmar Ferreira; MARTINS, Ives Gandra da Silva (coord.). A evolução do direito no século XXI: estudos em homenagem ao professor Arnoldo Wald. Coimbra: Almedina, 2007.

CAPPELLETTI, Mauro; GARTH, Bryant. Acesso à justiça. Tradução: Ellen Gracie Northfleet. Porto Alegre: Sergio Antonio Fabris Editor, 1988.

CARMONA, Carlos Alberto. Arbitragem e processo: um comentário à Lei n. 9.307/96. 2. ed. rev., atual. e ampl. São Paulo: Atlas, 2004.

CARNELUTTI, Francesco. Sistema di diritto processuale civile. Padova: Cedam, 1936.

CARVALHO, André Castro. Pele em jogo: a LINDB e as assimetrias ocultas no cotidiano do administrador público brasileiro. In: CUNHA FILHO, Alexandre Jorge Carneiro; ISSA, Rafael Hamze; SCHWIND, Rafael Wallbach (Coord.). Lei de introdução às normas do direito brasileiro: anotada: Decreto-lei n. 4.657, de 4 de setembro de 1942. São Paulo: Quartier Latin, 2019. v. 2, p. 438-444. 
CARVAlHOSA, Modesto. Considerações sobre a lei anticorrupção das pessoas jurídicas: Lei 12.846/2013. São Paulo: Revista dos Tribunais, 2015.

CASSESE, Sabino, Tendenze e problemi del diritto ammnistrativo. Rivista Trimestrale di Diritto Pubblico, Milano, Giuffrè, v. 54, n. 4, p. 901-912, 2004.

CHIOVENDA, Giuseppe. Instituições de direito processual civil. Tradução da 2. ed. italiana por J. Guimarães Menegale; acompanhada de notas por Enrico Tullio Liebman; com uma introdução do prof. Alfredo Buzaid. 2. ed. São Paulo: Saraiva, 1965. v. 2.

CIANCI, Mirna; MEGNA, Bruno Lopes. Fazenda Pública e negócios jurídicos processuais no novo CPC: pontos de partida para o estudo. In: CABRAL, Antonio do Passo; NOGUEIRA, Pedro Henrique (coord.). Negócios processuais. Salvador: Juspodivm, 2015. v. 1 , cap. 22 , p. 481-506.

CONSELHO ADMINISTRATIVO DE DEFESA ECONÔMICA (CADE). Guia Programa de Leniência do CADE. Brasília. 2017. p. 1-67. Disponível em: http://www.cade.gov.br/acesso-a-informacao/publicacoes-

institucionais/guias_do_Cade/guia_programa-de-leniencia-do-cade-final.pdf. Acesso em: 18 nov. 2019.

COOTER, Robert; ULEN, Thomas. Direito \& economia. 5. ed. Porto Alegre: Bookman, 2010 .

CRESPO, Mariana Hernandez; SANDER, Frank. Diálogo entre os professores Frank Sander e Mariana Hernandez Crespo: explorando a evolução do Tribunal Multiportas. In: ALMEIDA, Rafael Alves de; ALMEIDA, Tania; CRESPO, Mariana Hernandez (org.). Tribunal multiportas: investindo no capital social para maximizar o sistema de solução de conflitos no Brasil. Rio de Janeiro: Editora FGV, 2012. cap. 1, p. 25-38. Disponível em: https://bibliotecadigital.fgv.br/dspace/bitstream/handle/10438/10361/Tribunal\%20Multipor tas.pdf). Acesso em: 20 dez. 2019.

CRETELLA JÚNIOR, José. Das licitações públicas: (comentários à Lei Federal nº 8.666, de 21 de junho de 1993, republicada [...]). 18. ed., 3. tiragem, rev. e atual. inclusive de acordo com a Lei $n^{\circ} 10.520$, de 17 de julho de 2002 (Pregão), e Decreto $n^{\circ} 5.450$, de 31 de maio de 2005 (regulamento do pregão eletrônico). Rio de Janeiro: Forense, 2009.

CUÉLLAR, Leila; MOREIRA, Egon Bockmann. Administração pública e mediação: notas fundamentais. Revista de Direito Público da Economia, v. 16, n. 61, p. 119-145, jan./mar. 2018.

CUNHA, Leonardo José Carneiro da. A fazenda pública em juízo. 16. ed. rev., atual. e ampl. Rio de Janeiro: Forense, 2019.

DAKOLIAS, Maria. O setor judiciário na América Latina e no Caribe: elementos para reforma. Tradução: Sandro Eduardo Sardá. Washington, D.C.: Banco Mundial, 1996. (Documento Técnico, n. 319). Disponível em: https://www.anamatra.org.br/attachments/article/24400/00003439.pdf. Acesso em: 20 set. 2019. 
DINAMARCO, Cândido Rangel. A arbitragem na teoria geral do processo. São Paulo: Malheiros, 2013.

DINAMARCO, Cândido Rangel. A instrumentalidade do processo. 10. ed. rev. e atual. São Paulo: Malheiros, 2002.

DINAMARCO, Cândido Rangel. Instituições de direito processual civil. 9. ed., rev. e atual. segundo o novo Código de Processo Civil e de acordo com a Lei 13.256, de 4.2.2016 e a Lei 13.363, de 25.11.2016. São Paulo: Malheiros, 2017. v. 1.

DINAMARCO, Júlia Raquel de Queiroz. Arbitragem e administração pública. Revista de Processo, São Paulo, Revista dos Tribunais, v. 26, n. 101, p. 264-282, jan./mar. 2001.

DI PIETRO, Maria Sylvia Zanella. Direito administrativo. 25. ed. São Paulo: Atlas, 2013.

DI PIETRO, Maria Sylvia Zanella. Direito administrativo. 22. ed., 2. reimpr. São Paulo: Atlas, 2009.

DI PIETRO, Maria Sylvia Zanella. Direito administrativo. 18. ed. São Paulo: Atlas, 2005.

DI PIETRO, Maria Sylvia Zanella. Direito administrativo. 14. ed, São Paulo: Atlas, 2002.

DI PIETRO, Maria Sylvia Zanella. Discricionariedade administrativa na Constituição de 1988. São Paulo: Atlas, 1991.

DUARTE, Zulmar. A difícil conciliação entre o novo CPC e a Lei de Mediação. GEN Jurídico, 02 maio 2017. Disponível em: http://genjuridico.com.br/2017/05/02/dificilconciliacao-entre-o-novo-cpc-e-lei-de-mediacao/. Acesso em: 19 nov. 2019.

FALECK, Diego. Desenho de sistemas de disputas: criação de arranjos procedimentais consensuais adequados e contextualizados para gerenciamento e resolução de controvérsias. 2017. 200 p. Tese (Doutorado) - Faculdade de Direito da Universidade de São Paulo. São Paulo, 2017.

FALECK, Diego. Manual de design de sistemas de disputas: criação de estratégias e processos eficazes para tratar conflitos. Rio de Janeiro: Lumen Juris, 2017.

FALECK, Diego; TARTUCE, Fernanda. Introdução histórica e modelos de mediação. Disponível em: http://www.fernandatartuce.com.br/wpcontent/uploads/2016/06/Introducao-historica-e-modelos-de-mediacao-Faleck-eTartuce.pdf. Acesso em: 10 dez. 2019.

FARIA, Jose Eduardo. O direito na economia globalizada. São Paulo: Malheiros, 2002.

FARIAS, Juliana Guanaes Silva de Carvalho. Panorama da mediação no Brasil: avanços e fatores críticos diante do marco legal. Direito UNIFACS - Debate Virtual, n. 188, p. 1-19, 2016. Disponível em: https://revistas.unifacs.br/index.php/redu/article/view/4099/2812. Acesso em: 20 nov. 2019. 
FERNANDES, Flávio Sátiro. A inexigibilidade de licitação para contratação de serviços advocatícios. Fórum de Contratação e Gestão Pública, v. 8, n. 84, p. 25-30, out. 2009.

FERNANDES, Jorge Ulisses Jacoby. Contratação direta sem licitação. 9. ed. rev., atual. e ampl. Belo Horizonte: Fórum, 2011.

FIGUEIREDO, Lúcia Valle; FERRAZ, Sérgio. Dispensa e inexigibilidade de licitação. 3. ed. rev., ampl. e atual. de acordo com a Constituição Federal de 1988 e as Leis 8.666-93 e 8.883-94. São Paulo: Malheiros, 1994.

FILOMENO, José Geraldo Brito. Curso fundamental de direito do consumidor. São Paulo: Atlas, 2007.

FISHER, Roger; SHAPIRO, Daniel. Além da razão: a força da emoção na solução de conflitos. Tradução: Arão Shapiro. Rio de Janeiro: Imago, 2009.

FISHER, Roger; URY, William; PATTON, Bruce. Como chegar ao sim: negociação de acordos sem concessões. Tradução: Vera Ribeiro; Ana Luiza Borges. 2. ed. rev. e ampl. Rio de Janeiro: Imago, 2005.

FISS, Owen M. Against settlement. Yale Law Journal, v. 93, No. 6, p. 1.073-1.090, May 1984.

Disponível

em:

https://digitalcommons.law.yale.edu/cgi/viewcontent.cgi?article=6871\&context=ylj.

Acesso em: 12 dez. 2019.

FULLER, Lon L. The forms and limits of adjudication. Harvard Law Review, Harvard Law Review Association, v. 92, No. 2, p. 353-409, Dec. 1978. Disponível em: https://people.rit.edu/wlrgsh/Fuller.pdf. Acesso em 20 dez. 2019.

GABBAY, Daniela Monteiro. Mediação e judiciário no Brasil e nos EUA: condições, desafios e limites para a institucionalização da mediação no judiciário. Brasília, DF: Gazeta Jurídica, 2013.

GABBAY, Daniela Monteiro; CUNHA, Luciana Gross (coord.). O desenho de sistemas de resolução alternativa de disputas para conflitos de interesse público. Brasília, DF: Secretaria de Assuntos Legislativos do Ministério da Justiça, 2010. (Série Pensando o Direito, n. 38). Disponível em: https://www.justica.gov.br/seus-direitos/elaboracaolegislativa/pensando-o-direito/publicacoes/anexos/vol-

38_o_desenho_de_sistemas_de_resolucao_alternativa_de_disputas_para_conflitos_de_inte resse_publico_fgv.pdf. Acesso em: 20 dez. 2019.

GASPARINI, Diógenes. Direito administrativo. 10. ed. rev. e atual. de acordo com a Lei das Parcerias Público-Privadas (Lei n. 11.079/2004). São Paulo: Saraiva, 2005.

GICO JUNIOR, Ivo Teixeira. A tragédia do Judiciário: subinvestimento em capital jurídico e sobreutilização do Judiciário. 2012. 146 p. Tese (Doutorado em Economia) Universidade de Brasília (UnB), Brasília, 2012. 
GIMENEZ, Charlise Paula Colet; SPENGLER, Fabiana Marion. Contribuições da teoria da ação comunicativa de Jürgen Habermas nos meios complementares de tratamento de conflito: o estudo do multidoor courthouse system. Quaestio Iuris, Rio de Janeiro, v. 9, n. 1, p. 164-180, 2016. Disponível em: https://www.epublicacoes.uerj.br/index.php/quaestioiuris/article/view/18233/15781. Acesso em: 30 nov. 2019.

GOLDBERG, Stephen B. SANDER, Frank E. A. Selecting a mediator: an alternative (Sometimes) to a Former Judge. Litigation, v. 33, No. 4, p. 40-44, Summer 2007.

GOMES, Orlando. Contratos. 18. ed. atual. e anotada por Humberto Theodoro Júnior. Rio de Janeiro: Forense, 1998.

GRAU, Eros Roberto. Arbitragem e contrato administrativo. Revista Trimestral de Direito Público, São Paulo, n. 32, p. 14-20, 2000.

GRINOVER, Ada Pellegrini. Conferência sobre arbitragem na tutela dos interesses difusos e coletivos. Revista de Processo, São Paulo, v. 31, n. 136, p. 249-267, jun. 2006.

GRINOVER, Ada Pellegrini. Ensaio sobre a processualidade: fundamentos para uma nova teoria geral do processo. Brasília: Gazeta Jurídica, 2016.

GRINOVER, Ada Pellegrini. Os métodos consensuais de solução de conflitos no novo CPC. In: GRINOVER, Ada Pellegrini et al. O novo Código de Processo Civil: questões controvertidas. São Paulo: Atlas, 2015. p. 1-21.

GUERRA, Sérgio; PALMA, Juliana Bonacorsi de. Art. 26 da LINDB: novo regime jurídico de negociação com a Administração Pública. Revista de Direito Administrativo, edição especial, Rio de Janeiro, FGV, p. 135-169, nov. 2018. Disponível em: $<$ http://bibliotecadigital.fgv.br/ojs/index.php/rda/article/view/77653>. Acesso em: 26 nov. 2019.

GUERRERO, Luis Fernando. Convenção de arbitragem e processo arbitral. 2. ed. São Paulo: Atlas, 2014.

GUERRERO, Luis Fernando. Convenção de arbitragem e processo arbitral. 2008. 201 p. Dissertação (Mestrado) - Faculdade de Direito da Universidade de São Paulo, São Paulo, 2008. p. 127-146.

HAGSTROM, Carlos Alberto. A disciplina do relacionamento entre as instituições financeiras e seus clientes: Código de Defesa dos Clientes de Bancos: comentários às Resoluções 2878 e 2892, do CMN: $1^{a}$ parte. Revista de Direito Bancário, do Mercado de Capitais e da Arbitragem, São Paulo, v. 5, n. 17, p. 29-58, jul./set. 2002.

IGNACIO, Laura. PGE de São Paulo reduz volume de recursos ao STJ e Supremo. Valor Econômico, de 042019.2 nov. 2 Disponível em: https://valor.globo.com/legislacao/noticia/2019/11/04/pge-de-sao-paulo-reduz-volume-derecursos-ao-stj-e-supremo.ghtml. Acesso em: 15 dez. 2019. 
JUSTEN FILHO, Marçal. Comentários à lei de licitações e contratos administrativos: Lei 8.666/1993. 18. ed., rev., atual. e ampl. São Paulo: Revista dos Tribunais, 2019.

JUSTEN FILHO, Marçal. Curso de direito administrativo. 3. ed. rev. e atual. São Paulo: Saraiva, 2008.

JUSTIÇA em números 2016: ano-base 2015. Brasília: Conselho Nacional de Justiça (CNJ), 2016. Disponível em: https://www.conjur.com.br/dl/justicaemnumeros-20161.pdf. Acesso em: 20 ago. 2019.

KLEIN, Aline Lícia. A arbitragem nas concessões de serviço público. In: PEREIRA, Cesar Augusto Guimarães; TALAMINI, Eduardo (coord.). Arbitragem e poder público. São Paulo: Saraiva, 2010. p. 63-110.

LEFÈVRE, Mônica Bandeira de Mello. A vinculatividade e o controle dos acordos substitutivos da decisão administrativa. 2018. 265 p. Dissertação (Mestrado em Direito) Faculdade de Direito da Universidade de São Paulo. São Paulo. 2018.

LEVIN, A. Leo; WHEELER, Russell R. (ed.). The Pound Conference: perspectives on justice in the future: proceedings of the National Conference on the Causes of Popular Dissatisfaction with the Administration of Justice. St. Paul, Minn.: West Publ. Co., 1979.

LORENCINI, Marco Antonio Garcia Lopes. "Sistemas multiportas": opções para o tratamento de conflitos de forma adequada. In: SALLES, Carlos Alberto de; LORENCINI, Marco Antônio Garcia Lopes; SILVA, Paulo Eduardo Alves da (coord.). Negociação, mediação e arbitragem: curso básico para programas de graduação em direito. Rio de Janeiro: Forense, São Paulo: Método, 2012. p. 57-85.

LOGUE, Hugh. Interview with Jon Davies, outgoing CEO of Families Need Fathers. Family Law, 30 July 2010. Disponível em: https://www.familylaw.co.uk/news_and_comment/interview-with-jon-davies-outgoingceo-of-families-need-fathers-8652. Acesso em: 10 dez. 2019.

MANCUSO, Rodolfo de Camargo. A resolução dos conflitos e a função judicial no contemporâneo estado de direito (nota introdutória). Revista dos Tribunais, São Paulo, v. 98, n. 888 , p. 9-36, out. 2009.

MARIANI, Rômulo Greff. Arbitragens coletivas no Brasil. São Paulo: Atlas, 2015.

MARINELA, Fernanda, BOLZAN, Fabrício (org.). Leituras complementares de direito administrativo: advocacia pública. 2. ed. rev. e ampl. Salvador: Juspodium, 2010.

MARQUES NETO, Floriano Peixoto de Azevedo. Do contrato administrativo à administração contratual. Revista do Advogado, São Paulo, AASP, v. 29, n. 107, p. 74-82, dez. $2009 \quad$ Disponível em: https://edisciplinas.usp.br/pluginfile.php/211972/mod_resource/content/1/Do\%20Contrato $\% 20$ Administrativo $\% 20 \% \mathrm{C} 3 \% \mathrm{~A} 0 \% 20 \mathrm{Administra} \% \mathrm{C} 3 \% \mathrm{~A} 7 \% \mathrm{C} 3 \% \mathrm{~A} 3 \mathrm{o} \% 20 \mathrm{Contratual} \% 20$ -\%20Floriano\%20de\%20Azevedo\%20Marques\%20Neto.pdf. Acesso em: 26 nov. 2019. 
MARQUES NETO, Floriano Peixoto de Azevedo. A singularidade da advocacia e as ameaças às prerrogativas profissionais. Revista do Advogado, São Paulo, v. 27, n. 93, p. 39-42, set. 2007.

MARQUES NETO, Floriano Peixoto de Azevedo. A superação do ato administrativo autista. In: MEDAUAR, Odete; SCHIRATO, Vitor Rhein (org.). Os caminhos do ato administrativo. São Paulo: Revista dos Tribunais, 2011. p. 89-113.

MARQUES NETO, Floriano Peixoto de Azevedo; FREITAS, Rafael Véras de. Comentários à Lei $n^{o}$ 13.655/2018 (Lei da Segurança para a Inovação Pública). Belo Horizonte: Fórum, 2019.

MARTINS, Ricardo Marcondes. Arbitragem e administração pública: contribuição para o sepultamento do tema. Interesse Público, Belo Horizonte, Fórum, v. 12, n. 64, p. 85-104, nov./dez. 2010.

MATTOS NETO, Antonio José de. Direitos patrimoniais disponíveis e indisponíveis à luz da Lei de arbitragem. Revista de Processo, São Paulo, v. 30, n. 122, p. 151-166, abr. 2005.

MAZZILLI, Hugo Nigro. Compromisso de ajustamento de conduta: evolução e fragilidades: atuação do Ministério Público. Revista de Direito Ambiental, v. 11, n. 41, p. 93-110, jan./mar. 2006. Disponível em: http://www.mazzilli.com.br/pages/artigos/evolcac.pdf. Acesso em: 20 nov. 2019.

MEIRELLES, Hely Lopes. Contratação de serviços técnicos com profissional ou firma de notória especialização. Revista de Direito Público, São Paulo, v. 7, n. 32, p. 31-35, nov./dez. 1974.

MEIRELLES, Hely Lopes. Direito administrativo brasileiro. 27. ed., atual. por Eurico de Andrade Azevedo, Délcio Balestero Aleixo e José Emmanuel Burle Filho. São Paulo: Malheiros, 2002.

MEIRELLES, Hely Lopes. Direito administrativo brasileiro. 26. ed., atual. por Eurico de Andrade Azevedo, Délcio Balestero Aleixo, José Emmanuel Burle Filho. São Paulo: Malheiros, 2001.

MEIRELLES, Hely Lopes. Direito administrativo brasileiro. 16. ed. atual. pela Constituição de 1988. São Paulo: Revista dos Tribunais, 1991.

MELLO, Celso Antonio Bandeira de. O conteúdo jurídico do princípio da igualdade. 2. ed. São Paulo: Revista dos Tribunais, 1984.

MELLO, Celso Antonio Bandeira de. Curso de direito administrativo. 29. ed. rev. e atual. até a Emenda Constitucional 68, de 21.12.2011. São Paulo: Malheiros, 2012.

MELLO, Celso Antonio Bandeira de. Curso de direito administrativo. 17. ed. rev. e atual. São Paulo: Malheiros, 2004. 
MENDES, Aluisio Gonçalves de Castro; SILVA, Larissa Clare Pochmann da. Acesso à justiça: uma releitura da obra de Mauro Cappelletti e Bryant Garth a partir do Brasil 40 anos depois. Quaestio Iuris, Rio de Janeiro, v. 8, n. 3, p. 1.827-1.858, 2015. Disponível em: https://www.e-publicacoes.uerj.br/index.php/quaestioiuris/article/view/19385/14138. Acesso em: 30 nov. 2019.

MENKEL-MEADOW, Carrie. Roots and inspirations: a brief history of the foundations of dispute resolution. In: MOFFITT, Michael L.; BORDONE, Robert C. (coord.). The handbook of dispute resolution. San Francisco: Jossey-Bass, 2005.

MIRAGAYA, Rodrigo Bracet. Os meios de conformação das relações jurídicas no direito administrativo: entre atos unilaterais e contratos. 2016. 304 p. Tese (Doutorado) Faculdade de Direito da Universidade de São Paulo. São Paulo, 2016.

MIRANDA, Francisco Cavalcanti Pontes de. Tratado de direito privado: parte geral: introdução: pessoas físicas e jurídicas. São Paulo: Revista dos Tribunais, 1977. v. 1, t. 1.

MNOOKIN, Robert H. Bargaining with the devil: when to negotiate, when to fight. New York: Simon \& Schuster, 2010.

MNOOKIN, Robert H.; PEPPET, Scott R.; TULUMELLO, Andrew S. Beyond winning: negotiating to create value in deals and disputes. 2. ed. Cambridge, MA: Belknap Press of Harvard University Press, 2000.

MONTEIRO, Alexandre Luiz Moraes do Rêgo; CASTRO, Leonardo Freitas de Moraes. Direito tributário e arbitragem: uma análise da possibilidade e dos óbices ao juízo arbitral em matéria tributária no Brasil. Revista Tributária e de Finanças Públicas, São Paulo, v. 17, n. 88, p. 18-47, set./out. 2009.

MONTENEGRO, Manuel; ANDRADE, Paula. Dias Toffoli defende superar cultura do litígio por meio da mediação. Agência CNJ de Notícias, 26 set. 2018. Disponível em: https://www.cnj.jus.br/dias-toffoli-defende-superar-cultura-do-litigio-por-meio-damediacao/. Acesso em: Acesso em: 30 out. 2019.

MOREIRA NETO, Diogo de Figueiredo, Curso de direito administrativo: parte introdutória, parte geral, parte especial. 16. ed., rev. e atual. Rio de Janeiro: Forense, 2014.

MOREIRA NETO, Diogo de Figueiredo. Novos institutos consensuais da ação administrativa. Revista de Direito Administrativo, Rio de Janeiro, FGV, v. 231, p. 129-156, jan./mar. 2003. Disponível em: http://bibliotecadigital.fgv.br/ojs/index.php/rda/article/view/45823/45108. Acesso em: 19 set. 2017.

MOURÃO, Alessandra Nascimento Silva e Figueiredo (coord.). Resolução de conflitos: fundamentos da negociação para o ambiente jurídico. São Paulo, Saraiva, 2014. (Série GVlaw).

MOURÃO, Alessandra Nascimento Silva e Figueiredo. Técnicas de negociação para advogados. 4. ed. rev. São Paulo: Revista dos Tribunais, 2017. 
NOGUEIRA, Erico Ferrari. A arbitragem e sua utilização na administração pública. Revista da $A G U$, v. 8, n. 21, p. 125-141, jul./set. 2009. Disponível em: https://bdjur.stj.jus.br/jspui/bitstream/2011/63004/arbitragem_utilizacao_administracao_no gueira.pdf. Acesso em: 20 dez. 2019.

NUNES, Luiz Antonio Rizzatto. Curso de direito do consumidor. 2. ed. rev., modificada e atual. São Paulo: Saraiva, 2005.

NYLUND, Anna. Access to justice: is ADR a help or hindrance? In: ERVO, Laura; NYLUND, Anna (ed.). The future of civil litigation: acess to courts and court annexed mediation in the Nordic countries. Cham: Springer International, 2014. p. 325-344.

OLIVEIRA, Gustavo Henrique Justino de. A administração consensual como a nova face da Administração Pública no século XXI: fundamentos dogmáticos, formas de expressão e instrumentos de ação. In: OLIVEIRA, Gustavo Henrique Justino de. Direito administrativo democrático. Belo Horizonte: Fórum, 2010. p. 211-231.

OLIVEIRA, Gustavo Henrique Justino de. A arbitragem e as parcerias público-privadas. In: SUNDFELD, Carlos Ari (coord.). Parcerias público-privadas. 2. tiragem. São Paulo: Malheiros, 2007. p. 567-606.

OSTIA, Paulo Henrique Raiol. Desenho de sistema de resolução de conflito: sistemas indenizatórios em interesses individuais homogêneos. Dissertação (Mestrado) - Faculdade de Direito da Universidade de São Paulo, São Paulo, 2014.

OTONI, Luciana. Justiça protagoniza homologação de acordos dos planos econômicos. Agência CNJ de Notícias, 02 ago. 2019. Disponível em: https://www.cnj.jus.br/justicaprotagoniza-homologacao-de-acordos-dos-planos-economicos/. Acesso em: 18 out. 2019.

PAIXÃO, Leonardo André. A função política do Supremo Tribunal Federal. 2007. Tese (Doutorado) - Faculdade de Direito da Universidade de São Paulo, São Paulo, 2007.

PALMA, Juliana Bonacorsi de. Atividade normativa da administração pública: estudo do processo administrativo normativo. 480 p. 2014. Tese (Doutorado) - Faculdade de Direito da Universidade de São Paulo, São Paulo, 2014.

PALMA, Juliana Bonacorsi de. Atuação administrativa consensual: estudo dos acordos substitutivos no processo administrativo sancionador. 2010. 332 p. Dissertação (Mestrado em Direito do Estado) - Faculdade de Direito, Universidade de São Paulo, São Paulo, 2010.

PALMA, Juliana Bonacorsi de. A consensualidade na Administração Pública e o seu controle judicial. In: GABBAY, Daniela Monteiro; TAKAHASHI, Bruno (coord.). Justiça Federal: inovações nos mecanismos consensuais de solução de conflitos. Brasília: Gazeta Jurídica, 2014. p. 143-188.

PARENTE, Eduardo de Albuquerque. Processo arbitral e sistema. São Paulo: Atlas, 2012. 
PEIXOTO, José Roberto da Cunha. Elementos da negociação: critérios objetivos. In: MARASCHIN, Márcia Uggeri (coord.). Manual de negociação baseado na teoria de Harvard. Brasília: Escola da Advocacia-Geral da União Ministro Victor Nunes Leal (EAGU), 2017. p. 21-37.

PELUSO, Antonio Cezar. Mediação e conciliação. Revista de Arbitragem e Mediação, v. 8, n. 30, p. 15-19, jul./set. 2011.

PEREIRA, Caio Mário de Silva. Instituições de direito civil: contratos. 10. ed., 17. tiragem. Rio de Janeiro: Forense, 2001. v. 3.

PEREIRA, Victor Alexandre El Khoury M. Acordo de leniência na Lei Anticorrupção (Lei $\mathrm{n}^{\circ}$ 12.846/2013). Revista Brasileira de Infraestrutura, RBINF, Belo Horizonte, v. 5, n. 9, p. 79-113, jan./jun. 2016.

PEREZ, Marcos Augusto. O negócio jurídico administrativo. In: MEDAUAR, Odete; SCHIRATO, Vitor Rhein (org.). Os caminhos do ato administrativo. São Paulo: Revista dos Tribunais, 2011. p. 263-273.

PORTO, Antônio José Maristrello; GRAÇA, Guilherme Mello (col.). Análise econômica do direito (AED). Rio de Janeiro: FGV Direito Rio, 2013. Disponível em: https://direitorio.fgv.br/sites/direitorio.fgv.br/files/u100/analise_economica_do_direito_20 132.pdf. Acesso em: 22 nov. 2019.

PRESS, Sharon. Court-connected mediation and minorities. American Bar Association (ABA), 29 June $2017 . \quad$ Disponível em: https://www.americanbar.org/groups/dispute_resolution/publications/dispute_resolution_m agazine/2013/summer/court-connected-mediation-and-minorities/. Acesso em: $02 \mathrm{dez}$. 2019.

PUGLIESE, Antonio Celso Fonseca; SALAMA, Bruno Meyerhof. A economia da arbitragem: escolha racional e geração de valor. Revista Direito GV, São Paulo, v. 4, n. 1, p. 15-27, jan./jun. 2008. Disponível em: http://bibliotecadigital.fgv.br/ojs/index.php/revdireitogv/article/view/35168. Acesso em: 15 nov. 2019.

RIBAS, Antonio Joaquim. Consolidação das leis do processo civil: commentada pelo Conselheiro Dr. Antonio Joaquim Ribas; com a collaboração de seu filho Dr. Julio A. Ribas. Rio de Janeiro: Dias da Silva Junior, 1879. 2 v. Disponível em: http://www2.senado.leg.br/bdsf/handle/id/220533. Acesso em: 12 dez. 2019.

RIBAS, Antonio Souza; RIBAS, Lídia Maria Lopes Rodrigues. Arbitragem como meio alternativo na solução de controvérsias tributárias. Revista Tributaria e de Finanças Públicas, São Paulo, v. 13, n. 60, p. 223-247, jan./fev. 2005.

RICCI, Edoardo F. Desnecessária conexão entre disponibilidade do objeto da lide e admissibilidade da arbitragem: reflexões evolutivas. In: LEMES, Selma Ferreira; CARMONA, Carlos Alberto; MARTINS, Pedro Batista (coord.). Arbitragem: estudos em homenagem ao prof. Guido Fernando da Silva Soares, in memoriam. São Paulo: Atlas, 2007. p. 402-412. 
RODAS, João Grandino. Acordos de leniência em direito concorrencial: práticas e recomendações. Revista dos Tribunais, São Paulo, v. 96, n. 862, p. 22-33, ago. 2007.

RUNDLE, Olivia. Court-connected mediation programmes: implications for courts and the legal profession. p. 1-10. Disponível em: https://pdfs.semanticscholar.org/f883/156eb6b1406b40524cdc9f08a043a6fe5752.pdf. Acesso em: 30 nov. 2019.

SADDY, André; GRECO, Rodrigo Azevedo. Termo de ajustamento de conduta em procedimentos sancionatórios regulatórios. Revista de Informação Legislativa, ano 52, n. 206, p. 165-203, abr./jun. 2015.

SALAMA, Bruno Meyerhof. O que é "direito e economia"? In: TIMM, Luciano Benetti (org.). Direito e economia. Porto Alegre: Livraria do Advogado, 2008.

SALES, Lilia Maia de Morais; SOUZA, Mariana Almeida de. O sistema de múltiplas portas e o judiciário brasileiros. Direitos Fundamentais e Justiça, ano 5, n. 16, p. 204-220, jul./set. 2011. Disponível em: https://www.researchgate.net/publication/326707190_O_Sistema_de_Multiplas_Portas_e_ o_judiciario_brasileiro. Acesso em: 30. nov. 2019.

SALLES, Carlos Alberto de. Arbitragem em contratos administrativos. Rio de Janeiro: Forense, 2011.

SALLES, Carlos Alberto de; LORENCINI, Marco Antônio Garcia Lopes; SILVA, Paulo Eduardo Alves da (coord.). Negociação, mediação e arbitragem: curso básico para programas de graduação em direito. São Paulo: Método, 2012.

SALOMI, Maira Beauchamp. O acordo de leniência e seus aspectos penais. 2012. 293 p. Dissertação (Mestrado) - Faculdade de Direito da Universidade de São Paulo, São Paulo. 2012.

SANDER, Frank E. A. The multi-door courthouse: settling disputes in the year 2000 . Barrister, ABA Young Lawyers Division, v. 3, No. 18, Summer 1976.

SANDER, Frank E. A. Varieties of dispute processing, 70 F.R.D. 111, 130 (1976) FRD Federal Rules Decisions.

SANDER, Frank E. A. Varieties of dispute processing (1979) 70 FRD 111 Satellite Industry Association, "2005 Annual Statistics Report”, (2005).

SANDER, Frank E. A.; GOLDBERG, Stephen B. Fitting the forum to the fuss: a userfriendly guide to selecting an ADR procedure. Negotiation Journal, v. 10, No. 1, p. 49-68, 1994.

SANDER, Frank E. A., GOLDBERG, Stephen B.; ROGERS, Nancy H. Dispute resolution casebook: negotiation, mediation and other processes. 2nd ed. Boston: Little, Brown, 1992.

SANOMYA, Renata Mayumi. Mediação e conciliação com o poder público. 2019. 249 p. Tese (Doutorado) - Faculdade de Direito da Universidade de São Paulo, São Paulo, 2019. 
SANTOS, Diogo Palau Flores dos. Técnicas de negociação no âmbito institucional. In: MARASCHIN, Márcia Uggeri (coord.). Manual de negociação baseado na teoria de Harvard. Brasília: Escola da Advocacia-Geral da União Ministro Victor Nunes Leal (EAGU), 2017. p. 98-122.

SCAVONE JÚNIOR, Luiz Antonio. Manual de arbitragem. 4. ed. rev. atual. e ampl. São Paulo: Revista dos Tribunais, 2010.

SCHIRATO, Vitor Rhein; PALMA, Juliana Bonacorsi de. Consenso e legalidade: vinculação da atividade administrativa consensual ao direito. Revista Eletrônica sobre a Reforma do Estado (RERE), Salvador, Instituto Brasileiro de Direito Público, n. 24, dez./fev. 2011. Disponível em: http://www.direitodoestado.com.br/codrevista.asp?cod=485. Acesso em: 20 nov. 2019.

SICA, Heitor Vitor Mendonça. Arbitragem e Fazenda Pública. Disponível em: <http://www.academia.edu/12883545/2015_-_Arbitragem_e_Fazenda_P\%C3\%BAblica>. Acesso em: 10 dez. 2015.

SILVA, Paulo Eduardo Alves da. Mediação e conciliação, produtividade e qualidade. Revista do Advogado, São Paulo, AASP, v. 34, n. 123, p. 40-47, ago. 2014.

SOUZA, Rodrigo Pagani de. A legalização da teoria dos atos administrativos: apontamentos sobre os seus impactos na jurisprudência do STF. In: MEDAUAR, Odete; SCHIRATO, Vitor Rhein (org.). Os caminhos do ato administrativo. São Paulo: Revista dos Tribunais, 2011. p. 383-400.

SOUZA JÚNIOR, Lauro da Gama e. Sinal verde para a arbitragem nas parcerias públicoprivadas: a construção de um novo paradigma para os contratos entre o Estado e o investidor privado. Revista de Direito Administrativo, Rio de Janeiro, v. 241, p. 121-175, 2005.

STIGLER, George J. Law or economics? The Journal of Law \& Economics, v. 35, No. 2, p. 455-468, Oct. 1992.

SUNDFELD, Carlos Ari. Ato administrativo inválido. São Paulo: Revista dos Tribunais, 1990.

TARTUCE, Fernanda. Mediação no novo CPC: questionamentos reflexivos. Disponível em: $\quad$ www.fernandatartuce.com.br/wpcontent/uploads/2016/02/Media\%C3\%A7\%C3\%A3o-no-novo-CPC-Tartuce.pdf. Acesso em: 16 nov. 2019.

TARTUCE, Fernanda. Mediação nos conflitos civis. 3. ed. rev., atual. e ampl. Rio de Janeiro: Forense; São Paulo: Método, 2016.

TARTUCE, Fernanda. O novo marco legal da mediação no direito brasileiro. Revista de Processo, São Paulo, Revista dos Tribunais, v. 41, n. 258, p. 495-516, ago. 2016. 
TONIN, Mauricio Morais. Mediação e administração pública: a participação estatal como parte e como mediador de conflitos. In: NASCIMBENI, Asdrubal Franco; BERTASI, Maria Odete Duque; RANZOLIN, Ricardo Borges (org.). Temas de mediação e arbitragem III. 3. ed. São Paulo: Lex Editora, 2019. p. 171-204.

TORRES, Heleno Taveira. Transação, arbitragem e conciliação judicial como medidas alternativas para resolução de conflitos entre administração e contribuintes: simplificação e eficiência administrativa. Revista de Direito Tributário, São Paulo, n. 86, p. 40-64, 2003.

URY, William L.; BRETT, Jeanne M; GOLDBERG, Stephen B. Getting disputes resolved: designing systems to cut the costs of conflict. San Francisco: Jossey-Bass, 1988. (JosseyBass Management Series).

URY, William; BRETT, Jeanne; GOLDBERG, Stephen. Resolução de conflitos: concepção de sistemas para reduzir custos de conflitos. Tradução: Soares Franco. Lisboa: Actual Editora, 2009.

VITOVSKY, Vladimir Santos. O acesso à justiça em Boaventura de Sousa Santos. Revista Interdisciplinar de Direito, [S.1.], v. 13, n. 1, p. 177-196, ago. 2017. Disponível em: < http://faa.web1301.kinghost.net/revistas/index.php/FDV/article/view/68/48>. Acesso em: 21 dez. 2019.

WALTER, Carlos Humberto. Jurisdição constitucional e procedimentalidade arbitral no estado de direito democrático. Revista Tributaria e de Finanças Públicas, São Paulo, v. 16, n. 79, p. 98-108, mar./abr. 2008.

WAMBIER, Teresa Arruda Alvim et al. Primeiros comentários ao novo Código de processo civil: artigo por artigo: de acordo com a Lei 13.256/2016. 2. ed. rev. atual. e ampl. São Paulo: Revista dos Tribunais, 2016.

WANG, Daniel Wei Liang. Poder Judiciário e participação democrática nas políticas públicas de saúde. Dissertação (Mestrado) - Faculdade de Direito da Universidade de São Paulo, São Paulo, 2009.

WATANABE, Kazuo. Cultura da sentença e cultura da pacificação. In: YARSHELL, Flávio Luiz; MORAES, Maurício Zanoide de (coord). Estudos em homenagem à Professora Ada Pelegrini Grinover. São Paulo: DPJ, 2005. p. 684-690.

WATANABE, Kazuo. Modalidade de mediação. In: DELGADO, José et al. Mediação: um projeto inovador. Brasília: Centro de Estudos Judiciários, CJF, 2003. p. 42-50. (Cadernos do CEJ, v. 22).

WATANABE, Kazuo. Política pública do Poder Judiciário nacional para tratamento adequado dos conflitos de interesses. Disponível em: https://www.tjsp.jus.br/Download/Conciliacao/Nucleo/ParecerDesKazuoWatanabe.pdf. Acesso em: 07 maio 2019. 
YAMAMOTO, Ricardo. Arbitragem e administração pública: uma análise das cláusulas compromissórias em contratos administrativos. 2018. 202 p. Dissertação (Mestrado) Escola de Direito de São Paulo da Fundação Getulio Vargas, São Paulo, 2018. Disponível em: http://bibliotecadigital.fgv.br/dspace/handle/10438/25820. Acesso em: 20 nov. 2019.

ZANCANER, Weida. Da convalidação e da invalidação dos atos administrativos. 3. ed. São Paulo: Malheiros, 2008. 